
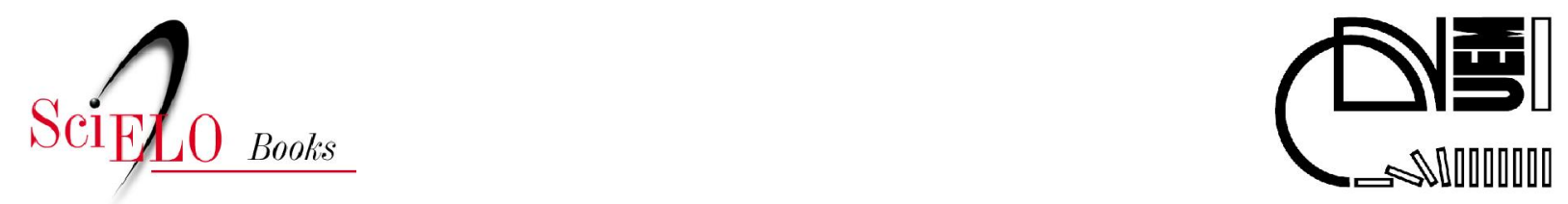

\title{
VIII. A situação agrária do norte novo e norte novíssimo do Paraná no início dos anos 1970
}

\author{
Paulo Astor Soethe (org.) \\ Daniel Martineschen (coord.) \\ Caio Heleno da Costa Pereira \\ Dionei Mathias \\ Elisete Antoniuk \\ Fernanda Boarin Boechat \\ Frederico Füllgraf \\ Natasha Pereira da Silva \\ Sibele Paulino \\ Sirlene Nair Neubauer \\ (transl.)
}

\section{SciELO Books / SciELO Livros / SciELO Libros}

SOETHE, PA., org. MARTINESCHEN, D., et al., transl. KOHLHEPP, G. A situação agrária do norte novo e norte novíssimo do Paraná no início dos anos 1970. In: Colonização agrária no Norte do Paraná: processos geoeconômicos e sociogeográficos de desenvolvimento de uma zona subtropical do Brasil sob a influência da plantação de café [online]. Maringá: Eduem, 2014, pp. 159-198. ISBN 978-85-7628-655-4. Available from SciELO Books < $\underline{\text { http://books.scielo.org }>\text {. }}$

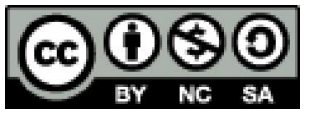

All the contents of this chapter, except where otherwise noted, is licensed under a Creative Commons Attribution-Non Commercial-ShareAlike 3.0 Unported.

Todo o conteúdo deste capítulo, exceto quando houver ressalva, é publicado sob a licença Creative Commons Atribuição Uso Não Comercial - Partilha nos Mesmos Termos 3.0 Não adaptada.

Todo el contenido de este capítulo, excepto donde se indique lo contrario, está bajo licencia de la licencia Creative Commons Reconocimento-NoComercial-CompartirIgual 3.0 Unported. 


\section{A SITUAÇÃO AGRÁRIA DO NORTE NOVO E NORTE NOVÍSSIMO DO PARANÁ NO INÍCIO DOS ANOS $1970^{303}$}

\section{DIFERENCIAÇÃO ESPACIAL DAS MUDANÇAS NA ESTRUTURA AGRÁRIA}

Desde o auge do cultivo do café no Norte do Paraná por volta de 1960, que se documentou como uma preponderância absoluta da área das plantações de café na utilização do solo (Mapa 27), ocorreram essenciais mudanças estruturais no âmbito agroeconômico. Primeiramente, a ampliação da área cultivada para regiões não propícias ao cultivo do café trouxe um relativo retrocesso da fração de área das plantações de café em relação à área cultivada. O risco de produção excessiva levou, alem disso, a uma absoluta redução direcionada das áreas de cultivo de café (ver Cap. VI). Essa tendência foi acentuada por diversos e fortes danos causados por geada, bem como pela erradicação espontânea conjuntural.

Em face do risco econômico de uma concentração unilateral sobre a plantação de café comprometida pela geada, o cultivo de produtos agrícolas anuais foi ampliado e - em caso de empreendimentos maiores - realizou-se a plantação em grande escala de pastagens artificiais para criação de gado (Fotos 8,14 e 16).

A estrutura do uso do solo nos anos de 1969/70 mostra essas mudanças em nível municipal (vide Mapa 34) ${ }^{304}$. Enquanto na região central e sul do Norte Novo, sobretudo os alimentos básicos passaram a ocupar - com algumas exceções - a maior parte área cultivada, e no norte dessa região as pastagens assumem essa posição. Somente nas regiões com condições de solo favoráveis e altitudes propícias, especialmente no âmbito das divisoras de águas principais, o cultivo do café nada perdeu da sua preponderância territorial.

Quase todo o noroeste e o oeste (Norte Novíssimo nas regiões de Paranavaí e Umuarama) tiveram uma rápida expansão das pastagens, que coincidiu, já em meados e ao fim dos anos 1960, com um forte decréscimo de rendimento no cultivo do café nos solos arenosos do Caiuá (Mapa 34).

A diferenciação espacial das tendências do desenvolvimento das mudanças estruturais na utilização do solo na área investigada entre 1960 e 1970 deve ser esclarecida com base em diagramas triangulares (Figuras 9, 10,11), que apresentam o desenvolvimento discrepante dentro das diversas regiões em valor mediano, bem como na concentração e dispersão dos valores (dentro das linhas pretas de demarcação nas Figuras 9-11, ver Mapa 35). Nisso as frações percentuais de culturas permanentes, de produtos agrícolas anuais e de pastagem serão observadas comparativamente na utilização do solo.

Na região de Londrina no Norte Novo podem ser constatadas, desde 1960, duas tendências de desenvolvimento claramente diferentes entre si (Figura 9). Mesmo que, no valor mediano, a fração da área de cultivo de café tenha diminuído pela metade, na região principal de cultivo de café (nas Figuras 9-11 e Mapa 35 indicados com I) foi fortemente ampliada a área ocupada por produtos de cultivo anual, enquanto se percebe, em parte, uma clara tendência de ampliação das pastagens no noroeste dessa região (II), dominado por terrenos arenosos. As cifras são apresentadas resumidamente na Tabela 39 (p. 308, Anexo) ${ }^{305}$.

303 Tradução de Caio Heleno da Costa Pereira e Elisete Antoniuk.

304 Os dados estatísticos do Mapa 34, em razão da falta de estatísticas oficiais até aquele momento, resultam de levantamentos próprios isolados feitos em 1970 em diversos municípios, bem como de levantamentos da fábrica de insumos Ultrafertil (filial de Londrina). Agradece-se aqui à firma pela possibilidade de avaliação desses dados internos da empresa. As estatísticas do Departamento Estadual de Estatística em Curitiba infelizmente não fornecem dados sobre as áreas de pastagem. O Ministério da Agricultura no Rio de Janeiro forneceu, para 1968, dados sobre as áreas de cultivo de culturas anuais em nível municipal. Para os municípios deixados em aberto no Mapa 34 não foram obtidos dados confiáveis. 
Figura 9: Mudanças na estrutura de uso do solo entre 1960 e 1970 (parcela da área cultivada):

Norte Novo de Londrina e Maringá.

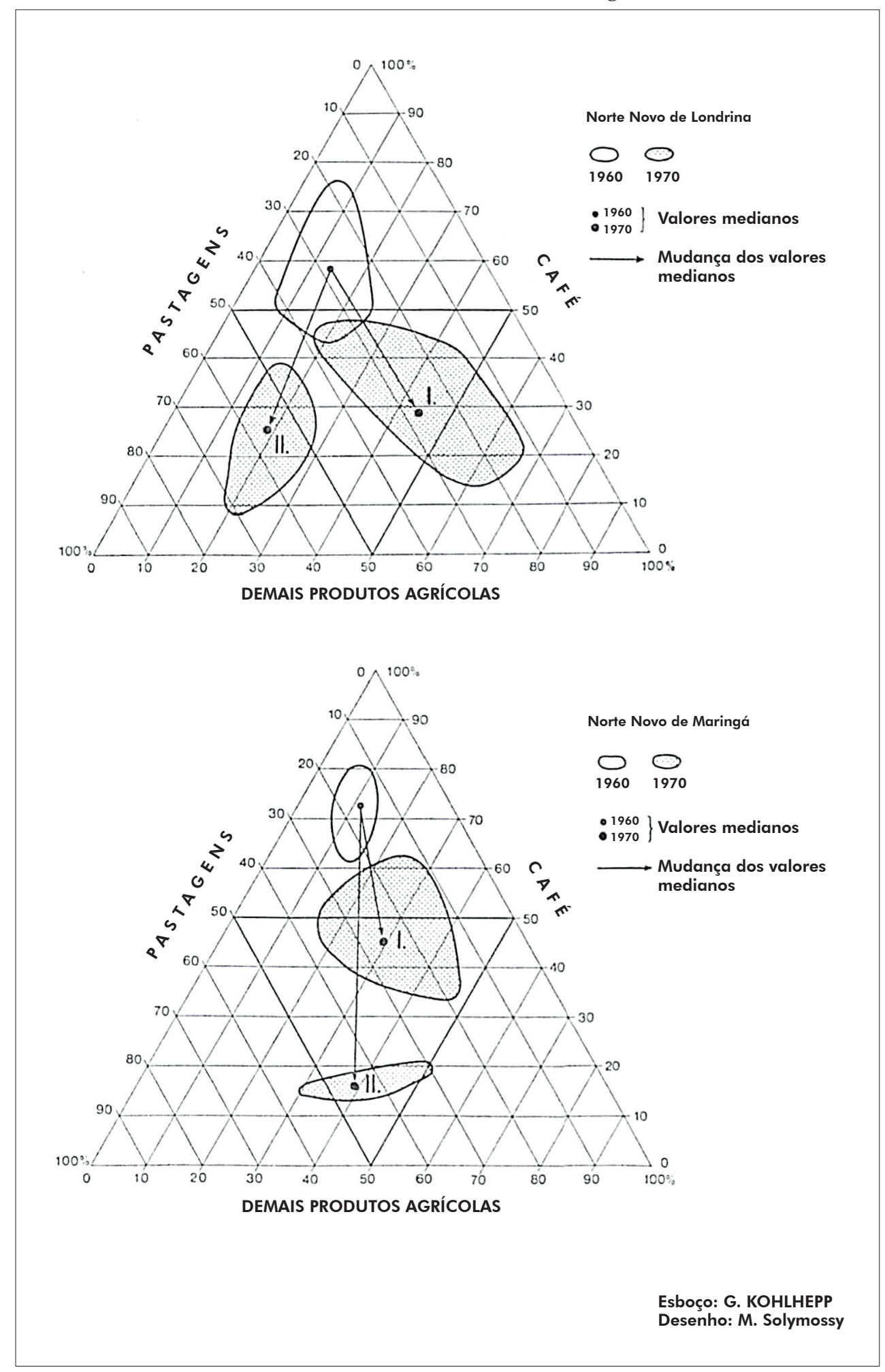

Fontes: Fig. 9-11: cf. Lista de Mapas, Mapa 34. 
Figura 10: Mudanças na estrutura de uso do solo entre 1960 e 1970 (parcela da área cultivada):

Norte Novíssimo.

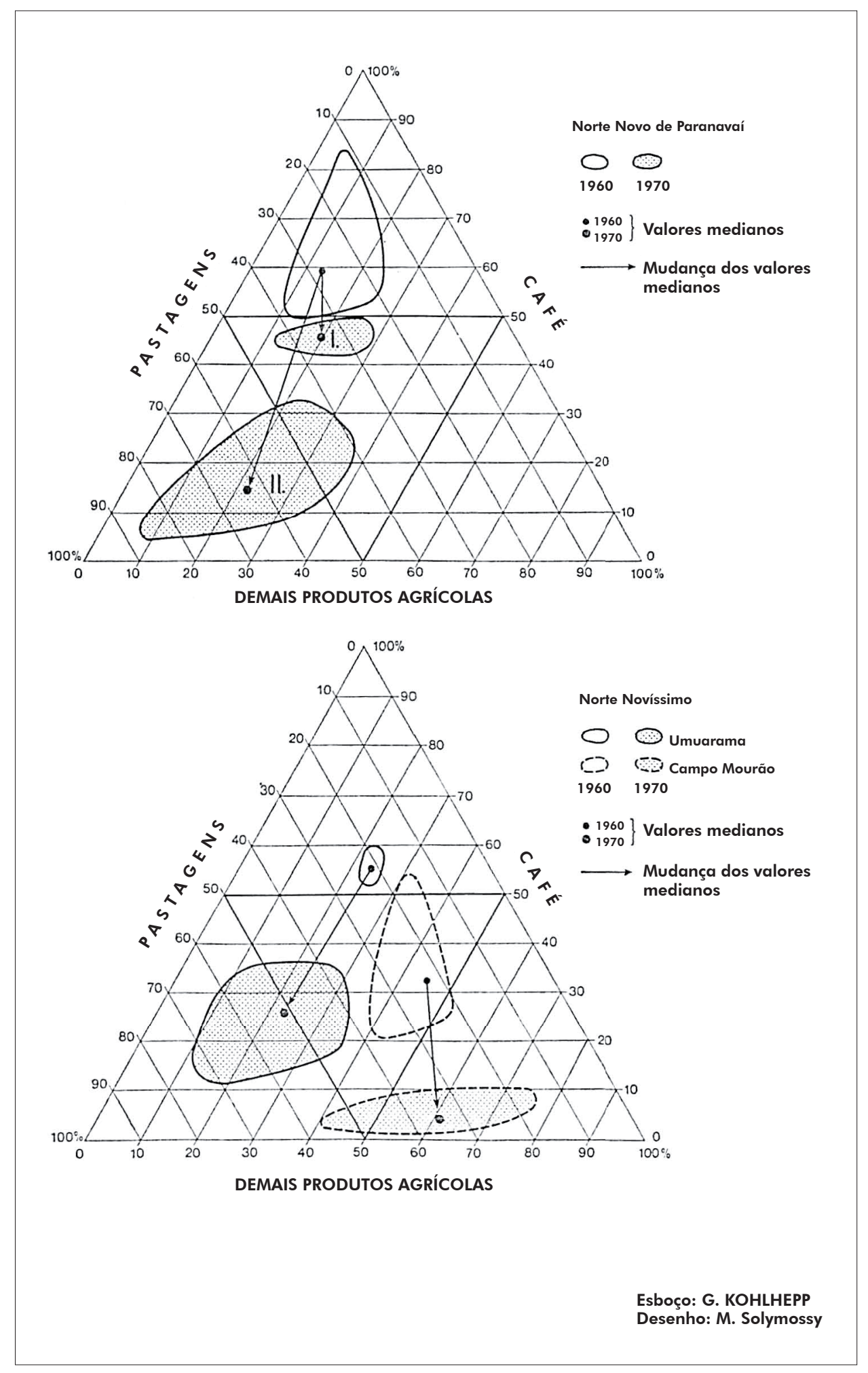


Figura 11: Mudanças na estrutura de uso do solo entre 1960 e 1970 (parcela da área cultivada):

Norte do Paraná e Norte Novo de Apucarana.

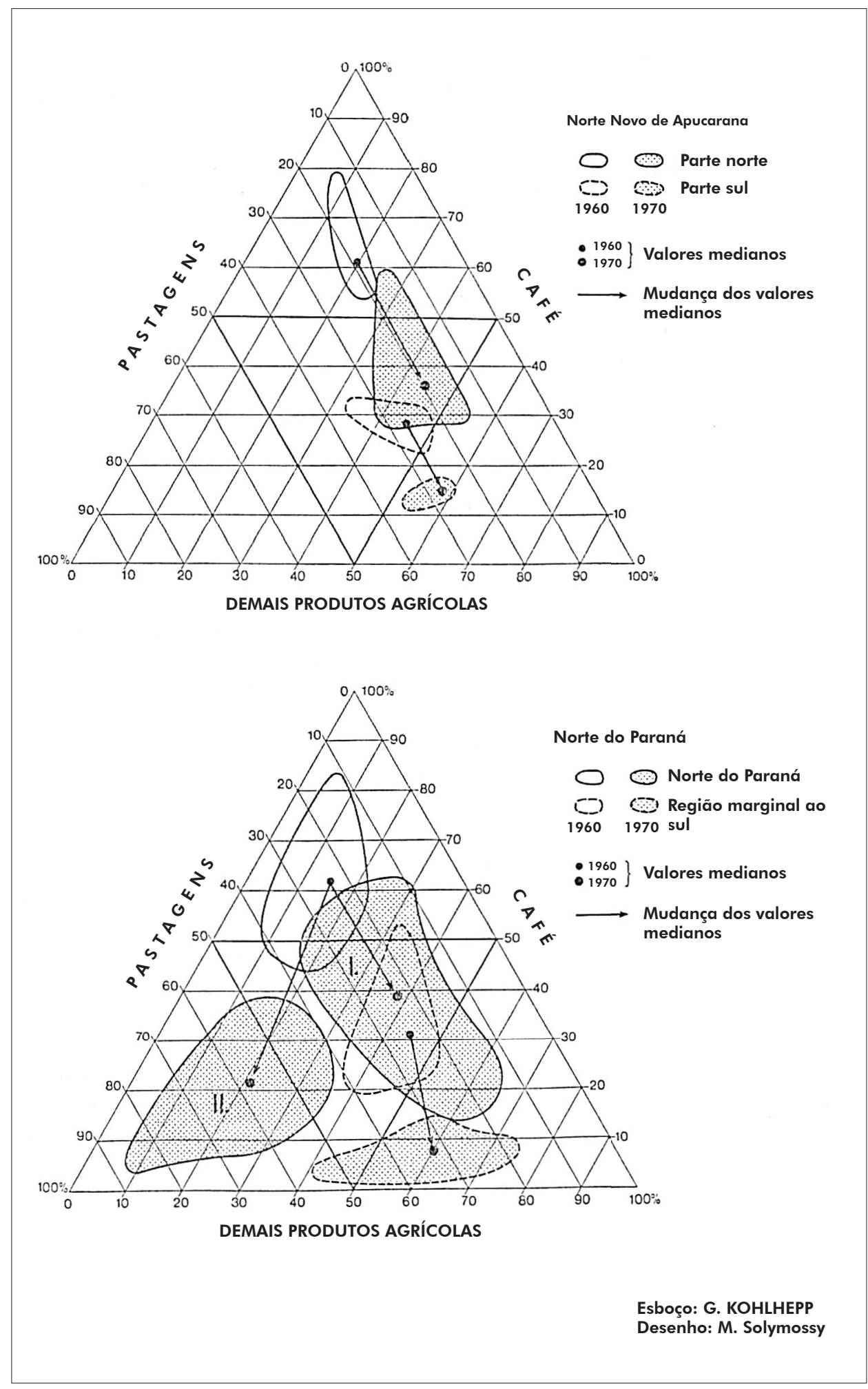


Em torno de Maringá, numa parcela da região central de cultivo do café, apesar de um evidente retrocesso, as plantações de café ainda ocupam quase a metade da área cultivada. O cultivo do café só foi fortemente reduzido nas áreas mais profundas, no vale do Ivaí e do Pirapó, em razão do risco de geada (Foto 9 e Mapa 35: II). O cultivo de alimentos básicos (milho, feijão, arroz, soja etc.) e a ampliação de pastos artificiais se deram aproximadamente na mesma medida.

O desenvolvimento da utilização do solo no Norte Novo de Apucarana é caracterizado por uma evidente diferença regional na importância do cultivo de café. No norte $(\mathrm{N})$, ainda hoje líder na área de cultivo, o plantio de café nas regiões marginais do sul (S) - com exceção de uma incidência em torno de Ivaiporã e Jardim Alegre - tem apenas uma importância reduzida, sobretudo por motivos climáticos. A redução da fração de área de cultivo de café na área cultivada ocorreu, tanto na região norte quanto na região sul, exclusivamente a favor da ampliação do plantio de milho, arroz e feijão ${ }^{306}$.

No Norte Novíssimo ao norte do rio Ivaí (região de Paranavaí, Figura 10, Mapa 35), o aumento da área cultivada ocorreu, desde 1960, com exceção da parte sudeste (I), na forma de implementação de pastagens de arroteamento, cuja área mais do que duplicou até 1970. A disseminação dos valores na região parcial II indica, na sua orientação geral, um forte direcionamento para a economia de pastagens. Através da erradicação direcionada, bem como, em grande medida, espontânea, foram utilizadas grandes áreas das antigas terras do café para o plantio de algodão, que ocupa hoje, em alguns municípios, mais do que $50 \%$ da área cultivada provida de produtos agrícolas anuais (Mapa 35). Na região parcial I do Norte Novissímo de Paranavaí, o plantio de café manteve sua posição predominante, pois na zona de transição de terra roxa e solos arenosos do Caiuá, a chamada terra roxa misturada possui uma maior fertilidade do que os solos arenosos puros do Noroeste. Além disso, o decurso da divisora de águas principal, com a possibilidade do plantio de café no cume dos morros, favorece esse desenvolvimento.

Ao sul do Ivaí, na região de Umuarama, observa-se uma evidente tendência para a economia de pastagens (Figura 10) que, em dez anos (1960-70), se fez notar em um aumento da fração de área na área cultivada de 21 para 51\%. A concentração dos valores isolados em 1960, que acentua a uniformidade da utilização do solo da época, cedeu, entretanto, no âmbito do desenvolvimento geral, a uma forte dispersão.

Na região de Campo Mourão, também na parte norte, as frações da área do plantio de café, ainda altas em 1960, diminuíram a valores entre 1 e 10\%, em razão do risco de geada. Enquanto as pastagens predominam somente em uma parte do noroeste dessa região, o plantio de milho, seguido pelo de arroz, feijão, soja e algodão, ocupa uma posição predominante (Figura 10 e Mapa 35).

A análise sintética (Figura 11) das mudanças estruturais do uso da terra no Norte Novo e Norte Novíssimo permite, porém, perceber um retrocesso das áreas de cultivo de café em todas as regiões, mas sua extensão varia fortemente conforme a região. Partindo-se dos valores médios, a tendência nas regiões parciais identificadas com 'I' (regiões principais de cultivo de café) (Mapa 35 e Tabela 39, p. 308, Anexo) indica claramente uma crescente importância da policultura, do plantio de alimentos básicos, de oleaginosas e de plantas têxteis, o que, entretanto, não prejudica o papel economicamente dominante do café. A fração de pastagens permaneceu inalterada (Figura 11: Norte do Paraná).

A discrepância do desenvolvimento na região II ocorre, principalmente, devido às diversas condições de solo da maior parte do Norte Novíssimo, onde preponderam os solos arenosos. A uma reduzida tendência à policultura (parcela do grupo dos produtos agrícolas anuais = demais produtos agrícolas em 1960: 15\%; em 1970: 21\%) contrapõe-se a expansão excepcionalmente forte das áreas de pastagem, que hoje ocupam, nessa região, quase $60 \%$ da utilização do solo. A orientação geral da dispersão dos dados isolados é claramente oposta em I e II.

\section{a) Tendências à policultura}

Para o desenvolvimento econômico do Norte do Paraná foi de grande importância, desde fins dos anos 50, a distribuição do risco na agricultura através do fomento de um cultivo variado. Nisso os alimentos básicos, característicos no Norte do Paraná em grande parte como plantações intermediárias no cultivo de café, ocuparam, a princípio, uma posição decisiva (Foto 6). Isso vale, sobretudo, para milho, arroz e feijão, que perfazem ao todo $90 \%$ de todas as culturas intermediárias.

306 Figura 11, Mapa 35 (N-S) bem como Mapas 27 e 34 (dados individuais por município). 
Tabela 40: Cultivos paralelos nos cafezais do Norte do Paraná em 1970 (parcela dos cultivos paralelos em relação à área total, em \%)

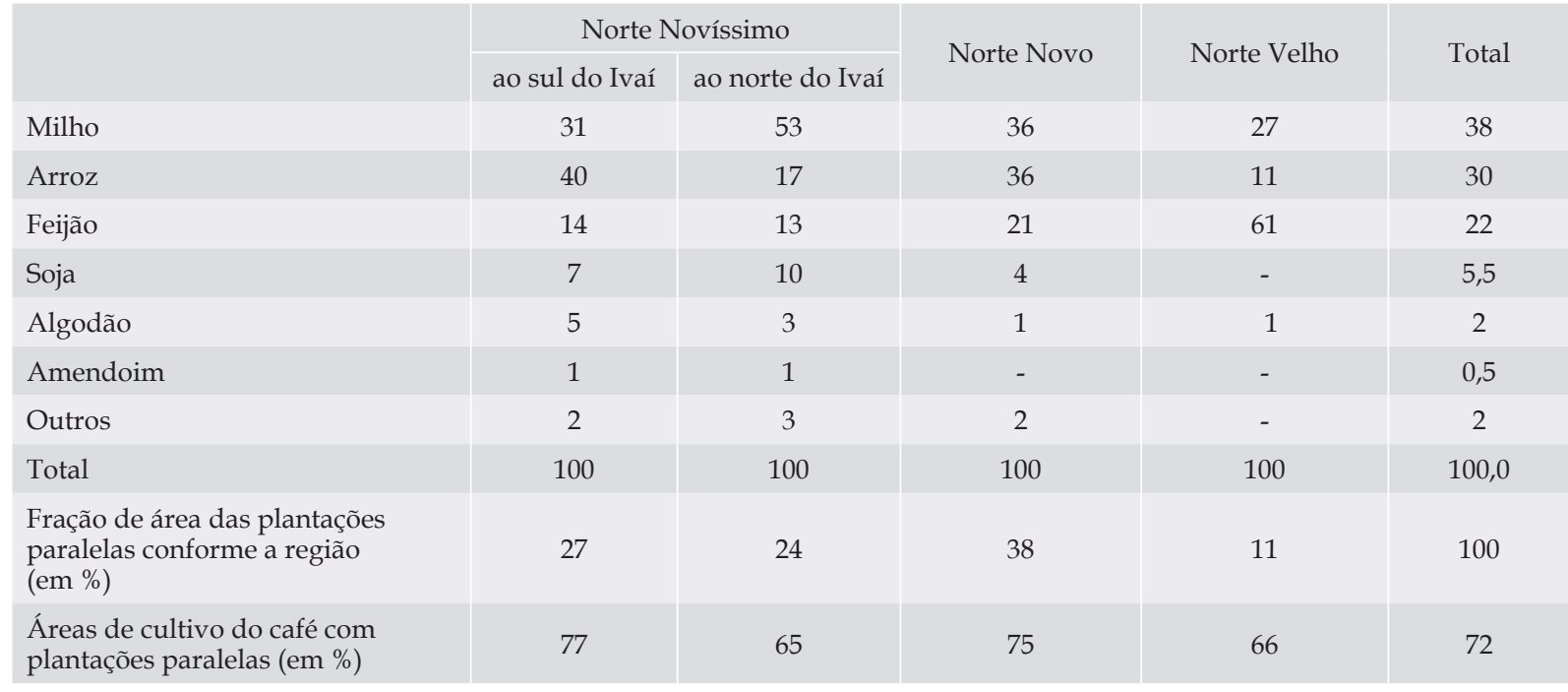

Fonte: Cálculos segundo documentos do Instituto Brasileiro do Café de 1970.

\section{Plantações paralelas}

No Norte Novo do Paraná, 75\% das áreas de cultivo do café possuem plantações paralelas, no Norte Novíssimo a porcentagem oscila entre 65 e $77 \%$.

$\mathrm{Na}$ área em estudo, privilegia-se especialmente milho e arroz, como plantações paralelas na lavoura de café. Ao contrário do Norte Velho, o plantio de feijão se coloca somente em terceiro lugar. O plantio de milho entre fileiras de cafeeiros predomina no Norte Novíssimo de Paranavaí, enquanto que ao sul do Ivaí prevalece o arroz. No Norte Novo a fração desses dois produtos agrícolas se iguala.

Especialmente disseminadas são as plantações paralelas no Norte Novo, onde milho, feijão e, sobretudo, arroz aparecem em grande escala como cultivo paralelo ao café. As respectivas áreas de cultivo desses produtos agrícolas e a forma do plantio como plantação paralela, plantação mista ou cultivo principal são apresentadas com base em valores municipais nos Mapas 36 a $38^{307}$. Em complementação a isso, a Tabela 41 (p. 310, Anexo) mostra as porcentagens de formas de cultivo de milho, arroz, feijão, soja e algodão em diferenciação regional. Dependendo da respectiva importância do plantio de café, diversos produtos agrícolas são cultivados quase que exclusivamente como plantação paralela (por exemplo, feijão na região de Maringá a 76\%). De toda a área de arroz no Norte Novo, $58 \%$ são plantações paralelas ao café. Na região de Umuarama são cultivados feijões somente em $4 \%$ da área de plantio como cultivo principal (região de Paranavaí: 31\%), porém 43\% como plantação paralela e $53 \%$ como plantação mista com outros produtos agrícolas. A porcentagem das plantações paralelas em toda a área de cultivo dos produtos agrícolas anuais corresponde, na área em estudo, para arroz a $40 \%$, feijão $32 \%$, milho $19 \%$, soja $13 \%$ e algodão $4 \%$ (Tabela 41 , p. 310, Anexo).

O plantio de culturas paralelas tem um fundamento tanto econômico como também ecológico. No novo plantio de café, o cultivo de alimentos básicos serve como uso principal da terra até a maturidade do cultivo permanente e, com isso, serve tanto para cobrir os meios de subsistência utilizados no empreendimento, como também - antes de a nova legislação dos agricultores entrar em vigor - como pagamento da força de trabalho em 'produtos naturais'. Porém, o uso suplementar da terra através de plantações paralelas somente pode ocorrer se não houver risco de prejuízos do cultivo principal com a subtração de nutrientes e água das plantações paralelas concorrentes. Com relação ao abastecimento

307 Os valores representados no Mapa 38 se referem ao feijão ('das águas'), plantado de agosto a outubro, que compõe 73\% das áreas de plantio de feijão. 
de água, o clima úmido do Norte do Paraná oferece evidentes vantagens em comparação com o clima alternadamente úmido de São Paulo central, com seus 3 a 4 meses áridos. No Norte Novo, a alta fertilidade do solo da 'terra roxa' garante um abastecimento suficiente de nutrientes para o cultivo principal e paralelo.

Os cultivos paralelos adquirem grande importância como proteção do solo contra excessiva insolação e influências da erosão do solo. Somente em casos raros a colheita da plantação paralela é sucedida pelo cultivo de leguminosas, tão importante para a adubação verde, sendo que estas não representam concorrência à plantação de café em relação à absorção de nitrogênio. Os cultivos paralelos abastecem o solo com importantes substâncias orgânicas e também contribuem para o melhoramento de suas qualidades físicas (SCHMIDT; MARCUS, 1943, p. 200-201). Na região dos terrenos arenosos do Noroeste, o cultivo das plantações paralelas é de extrema importância para evitar a lavagem entre as fileiras das árvores de café.

Enquanto o milho, o feijão e o arroz foram plantados tradicionalmente como culturas paralelas, sobretudo o plantio de soja aumentou nos últimos anos no Norte do Paraná, até a realização do presente estudo. Em razão da conjuntura favorável para plantas oleaginosas através da iniciativa do Banco Paranaense de Desenvolvimento com a implantação de uma indústria de óleo vegetal no início dos anos 1960, também foi recomendado pelo IBC o plantio de girassol como plantação paralela, mas isso pouco se consolidou. Por outro lado, na concessão de crédito pelo Banco do Brasil não são aceitas plantações de algodão e rícino entre as fileiras de árvore de café. Desde meados dos anos 1960 também não se pode mais plantar arroz nas recentes plantações de café financiadas pelo banco estatal. Essa medida tem motivos político-econômicos, pois há o risco de uma produção excessiva e não se apresentam possibilidades de exportação.

Tendo em vista que as plantações de café sensíveis à geada sofrem fortes oscilações de rendimento, o cultivo de produtos agrícolas anuais no Norte do Paraná tem a intenção de encontrar um segundo produto de cultivo economicamente favorável. Isso também explica a instabilidade das áreas de cultivo dos produtos agrícolas, cuja extensão depende da situação de preço correspondente. Como já acentuado na análise do uso da terra de antigas áreas de cultivo do café (ver Cap. VI, 3), as recomendações de cultivo de organizações estatais e privadas levaram a enormes oscilações, que na sequência se caracterizaram por produção excessiva e consequente queda de preço.

A situação apresentada no Mapa 35 para os anos de 1969/70 permite reconhecer uma evidente diferenciação espacial na plantação de produtos agrícolas anuais e combinações de produtos agrícolas ${ }^{308}$. No Norte Novo e no sul do Norte Novíssimo predomina o plantio de milho, que em uma série de municípios ocupa mais do que $50 \%$ ou mais do que um terço da área de cultivo das plantas anuais cultivadas. A comparação das áreas de cultivo no Mapa 36 confirma essa imagem, assim como a distribuição espacial da produção (Mapa 39). No sul do Norte Novo de Londrina, a plantação de arroz também assume maior importância.

Em toda a área dos terrenos arenosos, tanto no noroeste do Norte Novo como também em todo o Norte Novíssimo (especialmente ao norte de Ivaí), o cultivo de algodão tem posição predominante entre os produtos agrícolas anuais. O Mapa 35 mostra, de acordo com a quantidade de produtos agrícolas que ocupam acima de 5\% da área de cultivo, a concentração regional de algodão e milho. Mas ao mesmo tempo ele oferece uma impressão do avanço da diversificação dos produtos cultivados em proporção equilibrada das áreas dos produtos agrícolas e suas combinações standard (milho feijão - arroz; algodão - milho - feijão; algodão - milho - amendoim; arroz - feijão - soja) em grande número de municípios nos quais nenhum dos produtos anuais cultivados alcança um terço das áreas de cultivo.

Nas áreas pioneiras do Oeste e do Noroeste, o milho, o feijão, o algodão, o arroz e a soja frequentemente ocupam uma posição predominante ao fazer uso por alguns anos da fertilidade das áreas de floresta após o arroteamento. Isso ocorre tanto como plantação paralela no cultivo de café quanto como transição para a pecuária, em parte imediatamente após um curto intervalo do cultivo de algodão.

308 Cf. sobre isso os trabalhos metódicos para classificação estatística de crop combination regions e suas modificações em Weaver (1954a e b); Weaver (1956); Weaver, Hoag e Fenton (1956), bem como Scott (1957); Coppock (1964), que também considera as combinações de pecuária; Bhatia (1965), que investiga a crop concentration and diversification e nesse fundamento Mesquita e Silva (1970). 


\section{Algodão}

O fortalecido cultivo de algodão, que desde início dos anos 1930 vivenciou um boom a princípio em São Paulo como consequência da crise do café ${ }^{309}$ e trouxe para o Brasil uma diferenciação na estrutura de uso da terra (mas também na de exportação) ${ }^{310}$, pela primeira vez se distanciou da concentração da exportação de produtos agrícolas estimulantes (café, cacau, açúcar, banana) ${ }^{311}$.

O cultivo de algodão vivenciou um aumento significativo no Norte do Paraná na década de 1960 em função do risco de geada nas plantações de café, da procura por um produto agrícola economicamente favorável ao lado do café (ou até mesmo em substituição a este), e da fase de transição de amplas áreas do Noroeste para a economia de pastagens. De 1963 ate 1969, as áreas de cultivo do algodão aumentaram de 246.000 ha para 593.000 ha no Norte do Paraná, e a produção no mesmo período de 270.000 para $567.000 \mathrm{t}^{312}$. O Paraná teve participação de $25 \%$ na produção global do Brasil. Com isso, quase alcançou São Paulo como produtor de algodão em 1969, e assumiu o segundo lugar no Brasil.

No Norte do Paraná, o algodão alcançou, assim como o café, o limite meridional de cultivo no Brasil. O algodão, nas suas exigências climáticas, depende mais da temperatura do que da precipitação. Entretanto, o excesso de precipitação provoca grandes perdas na época da colheita, fator que enseja problemas especiais no Norte do Paraná. A planta exige bastante calor e possui um período de vegetação de seis meses, que deve ser livre de geada. Nisso a temperatura média do segundo ao quinto mês não deve ser inferior a $20^{\circ} \mathrm{C}^{313}$. No Norte do Paraná planta-se Gossypium hirsutum (algodão de terras altas/upland) com um comprimento de fibra de 30 a $32 \mathrm{~mm}$. Os arbustos, ao contrário dos cultivos plurianuais de g. barbadense (Sea-Island) no Nordeste do Brasil, são aproveitados somente durante um ano. A plantação ocorre de setembro a novembro, ou seja, após as últimas geadas, a colheita é realizada de março a abril/maio. O algodão prefere, sobretudo, solos arenosos argilosos profundos e solos argilosos arenosos, assim como terra roxa. Solos virgens especialmente ricos em nitrogênio (entre outros elementos) provocam um crescimento opulento de plantas, isso à custa da maturação das cápsulas. Por esse motivo, em recentes arroteamentos deveriam ser plantados, a princípio por um a três anos, milho, arroz e feijão, antes de se iniciar o cultivo de algodão (MORGENROTH, 1942a, p. 24-25). Contudo, isso raramente é feito no Norte Novíssimo. O cultivo ocorre geralmente como cultura principal, somente em pouca medida como plantação paralela ou cultura mista (vide Tabela 41 no anexo). Ainda é raro o cultivo de algodão em rotação regular de culturas. Em razão da fertilidade natural do solo planta-se algodão no mesmo campo inicialmente em anos seguidos. Mas isso logo leva a uma diminuição dos nutrientes do solo e a acentuada incidência de parasitas.

Os conhecimentos técnicos do cultivo de algodão no Norte do Paraná melhoraram um pouco após um começo evidentemente rudimentar no início dos anos 50. A colônia japonesa Assaí a leste do Rio Tibagi despontou como centro de inovação, para assumir a liderança, quantitativa e qualitativa, no cultivo de algodão do Paraná (Mapa 39, concentração a leste da região em estudo). A distribuição de sementes apropriadas por uma organização estatal afirmou-se de modo excelente.

Um forte incentivo à produção de algodão foram os baixos preços mínimos legalmente fixados para milho e amendoim, bem como a iniciativa estatal para o fomento da indústria de óleo vegetal ${ }^{314}$. A

309 A produção de algodão em São Paulo aumentou de 1930 até 1944 de 13.114 t para mais de 460.000 t (MATOS, 1954, p. 277, imagem IX).

310 No ano de 1969, a exportação de algodão representou 8,8\% do valor total de exportações do Brasil (IBGE, Anuário Estatístico do Brasil, 1970).

311 Matos (1954, p. 254) denominou a antiga agroeconomia orientada para a exportação como "agricultura de sobremesa".

312 A primeira estimativa de colheita para 1969 totalizou 687.000 t de algodão não descaroçado (segundo Rev. Paran. de Desenvolvimento n. 17, 1970, p. 29). Dados acima segundo: O Dirigente Rural. Anuário Rural (1970, p. 21).

313 No primeiro e no sexto meses a temperatura deve variar entre 15 e $18^{\circ} \mathrm{C}$, a temperatura mais baixa de germinação é entre 15 e $16^{\circ} \mathrm{C}$.

314 O conteúdo de óleo dos grãos de algodão varia de 12 a $21 \%$ e até $80 \%$ podem ser utilizados, enquanto o restante do óleo nos resíduos de prensa fica retido e pode ser utilizado como adubo e ração de gado. 
comercialização de algodão é bem organizada e se encontra em grande parte nas mãos de multinacionais e suas filiais ${ }^{315}$.

A importância do cultivo de algodão para o Norte do Paraná repousa na intensidade de trabalho da colheita e, com isso, na vinculação das forças de trabalho, que, nos anos com grandes danos no cultivo de café devido à geada, tem grande influência sobre a situação social geral.

Enquanto as operações no Norte Novo já estão em parte mecanizadas, nas áreas pioneiras do Norte Novíssimo - ou seja, em algo mais do que $50 \%$ de toda a área de cultivo de algodão do Paraná - falta quase que totalmente a mecanização. Nos recentes arroteamentos o algodão é plantado entre os tocos remanescentes e os troncos não removidos, e manejado com enxada. A colheita, que se estende por mais de 70 dias, é realizada em dois terços por trabalhadores itinerantes, cuja quantidade na colheita de algodão na região investigada deve corresponder a cerca de 70.000 pessoas (PEREIRA, 1968, p. 8-9). Os problemas da obtenção da força de trabalho na região de fronteira reduziram-se devido à quebra da safra do café, e hoje, no cultivo de algodão em geral predomina um excesso na oferta de força de trabalho.

No Norte do Norte Novo (região em torno de Colorado) e no Norte Novíssimo dominam maiores empreendimentos no cultivo de algodão. Diferentemente dos plantadores proprietários japoneses em torno de Assaí, o algodão é plantado no Noroeste do Paraná quase que exclusivamente por arrendatários e subarrendatários, cujas possibilidades econômicas são mínimas e que dependem do crédito que lhes é concedido pelos donos das terras junto ao Banco do Brasil. Muitas vezes atravessadores se imiscuem nisso, concedendo eles mesmos crédito aos arrendatários em condições bastante desfavoráveis. Assim, geralmente os meios financeiros para aumentar a produtividade através de adubo artificial e pesticida se apresentam somente em pequena monta. Plantações mistas de algodão com milho, feijão, rícino, amendoim etc. ou mais raramente como cultura paralela ao café, diminuem a produção em razão da concorrente subtração de nutrientes, especialmente nos solos arenosos do Norte Novíssimo, que rapidamente se esgotam.

Após excelentes resultados da colheita em 1968, a área de cultivo de algodão aumentou em 79\% em 1969, contudo a produção reduziu em torno de $38 \%{ }^{316}$. Em uma área de cultivo só pouco reduzida, a colheita de 1969/70 trouxe outra diminuição de produção de 1.121 kg/ha (1968/69) para 911 kg/ ha, depois de a produção média ainda ter sido de $1.649 \mathrm{~kg} / \mathrm{ha}^{317}$. Os motivos para essa extrema queda das colheitas são, sobretudo, as más condições climáticas (seca persistente, que adia a germinação das plantas; fortes precipitações em época de colheita) bem como a incidência extremamente forte de parasitas e a ocorrência de doenças nas plantas ${ }^{318}$.

Áreas de cultivo demasiadamente extensas dos arrendatários, poucos conhecimentos agronômicos, investimentos mínimos para a melhoria do solo e para a proteção das plantas e a discrepância na evolução dos preços de sementes, pulverização e trabalhos de colheita (1968-1969: + 30 até 50 \%) e preço de compra do produto final (1968-1969: + 8 \%) levaram a uma insegurança generalizada nos plantadores de algodão. A disseminação cada vez mais forte de parasitas de cápsula e de folha, paralelamente à alta excessiva dos preços de pulverização (que além disso geralmente se mostrou ineficiente), levou o Presidente da Associação dos Plantadores de Algodão a advertir publicamente sobre a continuação do cultivo ${ }^{319}$. Isso produziu um abandono do cultivo de algodão, expresso na transição para a criação extensiva de gado em empreendimentos maiores, e na adoção de plantação de soja e de grãos em pequenos e médios empreendimentos.

Em oposição ao algodão que avança de São Paulo para o sul, a disseminação de soja e trigo se relaciona com a migração interna de colonos gaúchos para o Norte do Paraná.

315 Sanbra; Anderson, Clayton \& Co., S.A.; Mc Fadden; Woolley-Dixon etc. Segundo dados da Indusfibra (Londrina) existiam, em 1970 no Norte Novo e Norte Novíssimo, 67 usinas de beneficiamento, instalações de desencaroçamento de algodão, limpeza, classificação etc., das quais 14 somente em Maringá e 10 em Umuarama.

316 Dados da Indusfibra, 1969, Relatório da Safra 1968/69.

317 Dados segundo a Folha de Londrina, suplemento técnico-agronômico ano 1, n. 9, 13/06/1970 e Indusfibra, 1969, Relatório da Safra 68/69.

318 Parasitas animais: Larva vermelha de cápsula (Parasitas de cápsula, folha e de rebento) (Platyedra gossypiella), Bemisia tabaci. Doenças de plantas: Spodoptera latisfascia; Agromyza sp. e capnodium sp. (segundo dados do agrônomo H. L. Pereira, Londrina).

319 Folha de Londrina, 30/06/70: Cultivar algodão é jogar dinheiro fora. 
Soja

O cultivo de soja se iniciou no Norte do Paraná desde os danos causados no cultivo de café pela geada de 1963. Em virtude da terra liberada quando foram arrancadas as árvores de café, o Instituto Brasileiro do Café colocou em circulação 10.000 t de sementes. Ate 1970 foram ampliadas as áreas de cultivo para 298.000 ha, e a produção aumentou para 279.000 t. Dessas, 45\% recaem sobre o Norte do Paraná (Mapa 40). A evolução favorável de preços, boas possibilidades de venda para o beneficiamento industrial (óleo vegetal, margarina, fabricação de sabão etc.), como produtos alimentícios para o mercado nacional bem como para a exportação e a possibilidade da mecanização dos processos de trabalho (por exemplo, colheita com ceifeira-debulhadora, também utilizada para a colheita de trigo) ofereceram pontos de partida para uma rápida expansão dessa cultura, que no afolhamento é cultivada com trigo. ${ }^{320}$

Tabela 42: Cultivo de trigo no Norte Novo e Norte Novíssimo do Paraná

\begin{tabular}{|c|c|c|}
\hline & $1966 / 67$ & $1969 / 70$ \\
\hline Qtd. de áreas de cultivo de trigo & 29 & 3.674 \\
\hline Área de cultivo em ha & 580 & 46.350 \\
\hline Produção em $t$ & 374 & 26.266 \\
\hline Produção kg/ha & 645 & 566 \\
\hline \multicolumn{3}{|l|}{ Parcela no Paraná (em \%): } \\
\hline Empreendimentos & 1,8 & 26 \\
\hline Área de cultivo & 3,6 & 24 \\
\hline Produção & 2,2 & 16 \\
\hline
\end{tabular}

Fonte: Quadro sinóptico segundo Ministério da Agricultura (CCLEF): Anuário Estatístico do Trigo. Safra 1966/67 e 1969/70.

\section{Trigo}

O plantio de trigo teve um extraordinário desenvolvimento desde o auge da segunda fase da redução da área de plantio de café em 1966/67, atingindo a $22^{\circ}$ de latitude sul seu limite de cultivo setentrional no Brasil. A favorável evolução de preços e um fomento estatal reforçado do cultivo ${ }^{321}$ contribuíram decisivamente para a expansão das áreas de cultivo (Tabela 42). Ao contrário do algodão, o trigo não é cultivado nos solos arenosos do Noroeste. Um forte avanço do cultivo de trigo do Rio Grande do Sul chega até a fronteira sudoeste da região em estudo junto ao Rio Piquiri, onde termina a migração interna da população teuto e ítalo-brasileira (Toledo, General Rondon) na fronteira do cultivo de café. As áreas centrais de cultivo de trigo no Norte do Paraná se localizam na região de terra roxa, sobretudo nas áreas marginais no sul do Norte Novo de Apucarana e na região de Campo Mourão, onde o vale do Ivaí se destaca (Mapa 41). Como o cultivo de café ocupa as regiões altas entre 400 e $800 \mathrm{~m}$, as plantações de trigo se encontram nas regiões altas e na exposição sul da encosta, com acentuado risco de geada como, por exemplo, nas regiões marginais do cultivo de café, ou na região de vale com inversão de temperatura no declive médio e inferior abaixo das plantações de café que se estendem nas encostas superiores. Isso traz consigo grandes problemas de erosão do solo que só foram solucionados por poucas empresas através da instalação de diques paralelos ao declive (Mapa 54, Fotos 9 e 14).

320 O Brasil vivenciou nestes últimos anos, até a realização desta pesquisa, um extraordinário boom no cultivo da soja e ocupa a terceira posição na produção mundial de soja. A produção brasileira de soja aumentou seis vezes de 1968 até 1973 , a exportação de soja e produtos de soja ficou em segundo lugar em 1973 no Brasil com US\$ 916,8 milhões, depois do café (US\$ $1.244,3$ milhões).

321 A importação de trigo representa no Brasil 11\% de todo o valor de importação. Esses gastos devem ser diminuídos através da ampliação do cultivo próprio. 
O crescimento da produção de trigo se deve exclusivamente ao aumento da área de cultivo. A produção média em 1969/70 foi menor em comparação a 1966/67, e com 566 kg/ha também se encontra substancialmente abaixo do valor médio para o Paraná. Por um lado, deve-se buscar o motivo para essas baixas produções na falta de experiência dos plantadores, para os quais o cultivo de trigo ainda se encontra em estágio experimental; por outro lado, a aplicação de adubo é pouco disseminada e a escolha da área não é adequada às condições climáticas. ${ }^{322}$

Uma análise do cultivo de trigo em cinco municípios selecionados segundo características regionais (Astorga, Marialva, Jardim Alegre, Campo Mourão e Cianorte) ${ }^{323}$ permite inferir que, somente no município de Campo Mourão, em 17\% dos empreendimentos com lavoura de trigo, $32 \%$ da área de cultivo foram adubados. A quantidade de adubo por hectare correspondeu somente quase à metade $(74 \mathrm{~kg} / \mathrm{ha})$ do valor médio, de toda forma reduzido, do Paraná. Em todos os outros municípios - com exceção de um empreendimento extensivo em Marialva - o trigo não foi adubado. Nisso, $93 \%$ da área de cultivo são trabalhados pelo proprietário e somente $7 \%$ são terras arrendadas. $14 \%$ dos empreendimentos tem uma área de cultivo de trigo de até dois hectares (fração de área 1,5\%), 38\% entre dois e cinco hectares (11\%), 22\% entre cinco e 10 hectares (15\%), e $15 \%$ se situavam entre 10 e 20 hectares em uma parcela de $18 \%$ de toda a área de cultivo de trigo. Somente $7 \%$ dos empreendimentos plantam trigo em mais de 20 hectares, a fração de área desses empreendimentos perfaz, porém, $54,5 \%$.

A parcela das plantações realizadas com créditos do Banco do Brasil oscilou entre zero (Cianorte) e 68\% (Campo Mourão) da área de cultivo de trigo por município. A maioria dos empreendimentos prefere por conta própria o cultivo primitivo sem rotação regular de culturas, em vez dos contratos oficiais, que têm uma série de exigências (adubação, mecanização, medidas protetivas contra erosão do solo etc.). Nos municípios citados a colheita de trigo é feita em $81 \%$ dos empreendimentos de forma manual. Somente $10 \%$ têm uma ceifeira-debulhadora à disposição, que pertence a grandes latifundiários e é emprestada.

Para o desenvolvimento futuro do cultivo de trigo no Norte do Paraná (que teve, desde 1970, outra forte expansão, ainda não registrada estatisticamente enquanto se escreve este livro) é de importância decisiva o cultivo de tipos de trigo resistentes à ferrugem. Até o momento seguem ocorrendo danos à colheita em razão do ataque da ferrugem. A irregularidade das precipitações levou frequentemente, nos últimos anos, à semeadura tardia (em geral, de abril a meados de junho), de forma que a colheita (de setembro a novembro) se estendeu até o fim do ano e o trigo sofreu com as altas precipitações e umidade do ar. O cultivo de trigo ainda tem cunho especulativo. Elevada aplicação de adubos artificiais, a ampliação da assistência agroeconômica tanto por organizações estatais (Acarpa) quanto por firmas privadas (indústria de adubo e de máquinas agrícolas) e a introdução de tipos de trigo mexicanos podem se tornar pontos de partida de uma crescente estabilização do cultivo de trigo, visto que a disponibilização de créditos e a garantia de preços mínimos pelo governo, que controla todo o comércio, oferecem aos plantadores boas possibilidades iniciais.

\section{Rami}

Na busca por uma complementação econômica para as plantações de café no caso de danos causados por geada, foi introduzida no Norte Novo a rami perene (Boehmeria nivea), principalmente por colonos japoneses. A rami foi introduzida em 1934 em São Paulo, proveniente do Japão. No Paraná, o centro de inovação dessa cultura era a colônia japonesa de Uraí, no Norte Velho. A rami, uma fibra vegetal em forma de arbusto, pertencente à família Urticaceae e com origem no leste asiático, destaca-se pela alta produtividade em um solo de húmus profundo, levemente ácido e rico em nutrientes. A fibra mede até $60 \mathrm{~cm}$ de comprimento e é extremamente resistente, possuindo uma superfície lisa, resistente à umidade e ao apodrecimento, podendo ser utilizada

322 'Frontana' e 'IAS-20 iassul' são as variedades de trigo mais disseminadas. Mas a primeira vem sendo cada vez mais substituída por IAS-20, que deve apontar um aumento de $70 \%$ no rendimento (Coopercotia, Dez. 1967, p. 23). Um grupo de especialistas alemães está realizando, enquanto este livro é escrito, tentativas de cultivo de novas variedades de trigo no Segundo Planalto em Ponta Grossa no Paraná, no âmbito de um projeto de desenvolvimento.

323 Segundo CCLEF, Anuário de Estatístico do Trigo: Safra 1969/70 e Dados da Acarpa, Curitiba. 
de diversas maneiras. ${ }^{324}$ Com três cortes úteis por ano ${ }^{325}$, o cultivo de rami oferece, por mais de 10 anos, 5 a 10 vezes mais quantidade de fibra por área, em comparação com o algodão. Embora a rami seja sensível à geada, as geadas noturnas não danificam as suas raízes, de modo que a planta pode continuar a brotar. Uma vez que nenhum corte útil ocorre no inverno, a rami, que de abril a novembro não requer nenhum procedimento de trabalho, adequa-se bem à organização do trabalho em plantações de café, onde ocorre neste período a intensa e laboriosa colheita do café.

As fortes geadas de 1953 e 1955 forçaram a diversificação dos produtos agrícolas e levaram à expansão do cultivo de rami no Norte Novo do Paraná. Depois da geada de 1955, os trabalhos só puderam ser continuados em muitas plantações extensas de café devido aos rendimentos das plantações de rami. ${ }^{326}$ Uma vez que as geadas não impedem o crescimento de rami, a área das plantações fica, em geral, no caso de relevo levemente ondulado, no terço inferior da encosta (Mapa 54), ou seja, na região em que se evitam as plantações de café devido a possíveis danos causados por geadas.

O problema enfrentado pela adicional expansão do cultivo de rami, que compreende atualmente a cerca de 8.500 hectares no Norte Novo e Novíssimo, é a carência de capital para a aquisição de pequenas máquinas móveis para o desfibramento, bem como a mão de obra com o processo de desfibramento e com o subsequente processo de degomagem. A construção de uma indústria de processamento também traz dificuldades, uma vez que, devido ao seu comprimento, as fibras não podem ser processadas em fiações de algodão. As fiações e as tecelagens de rami localizamse no Estado de São Paulo, sendo a comercialização das fibras secas em grande parte assumida pela Cooperativa Agrícola de Cotia. Os plantadores têm contratos fixos, obtendo bons preços a uma demanda sempre crescente - apesar da concorrência de fibras sintéticas e de algodão. Se o processo de desfibramento puder ser melhorado por meio de máquinas agrícolas maiores e com um desempenho diário mais alto, então pode haver uma chance de exportação para a cultura de rami (WILHELMS, 1963, p. 64-73).

\section{A importância da 'Cotia' para o desenvolvimento da policultura}

A Cooperativa Agrícola de Cotia (CAC ou Cotia), que foi fundada em 1927 por colonos japoneses em Cotia (a $30 \mathrm{~km}$ de São Paulo) ${ }^{327}$ e que tem sua sede principal em São Paulo, oferece uma importante contribuição para a expansão da policultura e para ampliação da oferta de produtos agrícolas. No fim da década de 1930, a cooperativa estendeu seu empreendimento a todo o Estado de São Paulo. Hoje, a 'Cotia' é a maior cooperativa agrícola da América Latina. A sua área de influência é dividida em 8 zonas, ${ }^{328}$ nas quais as cooperativas regionais têm sede, e onde existem mais de 80 depósitos, entre os quais 19 estão no Norte do Paraná. Entre os 11.500 membros da cooperativa, 3.300 vivem no Norte do Paraná (maior cooperativa regional), entre os quais 1.660 no Norte Novo e Novíssimo. 52\% dos membros são de nacionalidade japonesa (imigrantes), 44\% são brasileiros; a maioria, no entanto, é de ascendência japonesa (geração dos filhos), e os demais estão distribuídos entre imigrantes de 45 nacionalidades. ${ }^{329}$

Os produtos agrícolas dos membros são entregues nos depósitos regionais e, de acordo com as diretrizes das centrais, são entregues ao mercado a bons preços, com uma organização exemplar, que compreende até o transporte. Além disso, a cooperativa possui uma organização exportadora própria.

A CAC realiza consultoria agrícola junto a seus membros, organiza a venda mais barata de fertilizantes e possui numerosas instalações industriais (abatedouros, fábricas de conservas, produção

324 Utensílios domésticos (roupa de cama e de mesa, cobertas), vestimentas (na II Guerra Mundial, os uniformes de luta do exército japonês eram feitos de rami por sua resistência e secagem rápida) e utilização técnica (tubos, tecidos, planos, redes, cintos, faixas etc.) (WILHELMS, 1963, p. 7ss.)

325 Cerca de 70 dias depois do começo de novembro até meados de março. Em Rolândia: colheitas de 1.200 a 2.000 kg de fibra seca por hectare (dados gentilmente cedidos pelo sr. Bresslau, de Rolândia)

326 Cf. artigo Desenvolve-se a produção de rami na região norte do Paraná. Indústria Têxtil, dez. de 1957, p. 20 (Rio de Janeiro)

327 A CAC foi fundada por 82 plantadores de batatas, com a ajuda de um empréstimo do governo japonês. Na década de 1930, determinou-se que a venda de legumes e de tomates seria o ponto central da CAC, e a partir de 1935 organizou-se também a venda de ovos (cf. sobre isso ANDO, 1961)

328 'Cinturão verde' de São Paulo, Rio de Janeiro, norte, oeste e sudoeste de São Paulo, norte e sul do Paraná e sul do Mato Grosso.

329 Relatório dos Serviços Sociais, 1969 e informações gentilmente fornecidas pela direção da CAC, São Paulo - quantidade de membros correspondente ao início de 1970. 
de óleo vegetal, fabricação de chá, unidades de processamento e classificação para diversos produtos agrícolas, entre outros também para o café). Além disso, é ligada a ela uma cooperativa de crédito agrícola própria, bem como instalações sociais e culturais.

Os membros da CAC possuem, em grande parte, empreendimentos agrícolas pequenos e médios (Foto 8), mas também grandes empreendimentos de fazendeiros não japoneses estimam a efetividade da organização. A parcela anteriormente alta de arrendatários japoneses entre os membros diminuiu, uma vez que a maior parte deste grupo adquiriu propriedades. A direção sólida dos negócios da CAC também é responsável por esse desenvolvimento, protegendo seus membros da exploração dos atravessadores, através de garantias de preço e pré-financiamento para condições mais vantajosas e possibilitando uma venda dos produtos agrícolas com preços favoráveis também para os empreendimentos situados em locais mais afastados.

Tabela 43: Comercialização de produtos agrícolas dos membros da Cotia em 1969 (em \% do valor total)

\begin{tabular}{|c|c|c|c|}
\hline & Área total de captação & & Norte Novo e Novíssimo do Paraná \\
\hline Batatas & 18 & & - \\
\hline Ovos & 17 & & 24 \\
\hline Aves & 10 & & 3 \\
\hline Algodão & 8 & & 16 \\
\hline Café & 7 & & 28 \\
\hline Tomates & 6 & & 0,6 \\
\hline Óleo de amendoim & 5 & Soja & 14 \\
\hline Bananas & 2 & Uvas & 3 \\
\hline Chá & 1,5 & Milho & 2,5 \\
\hline Rami & 1,2 & & 6 \\
\hline \multirow[t]{2}{*}{ Demais produtos (95) } & 24,3 & & 2,9 \\
\hline & 100,0 & & 100,0 \\
\hline Volume em milhões de Cruzeiros & 263,4 & & 28,3 \\
\hline
\end{tabular}

Fonte: Dados gerais da CAC, São Paulo; para a região de estudo no Paraná, entrevistas próprias feitas pelo Autor nos depósitos.

A CAC possui depósitos no Norte Novo em Londrina, Rolândia, Arapongas, Apucarana, Maringá e Mauá, no Norte Novíssimo em Nova Esperança, Diamante do Norte e em Cruzeiro do Oeste. A entrada de produção mais representativa é apresentada por Maringá (soja 36\%, algodão 27\%, café $17 \%$ ), Londrina (café 35\%, ovos 25\%, rami 17\%), Nova Esperança (ovos 56\%, café $28 \%$ ) e Cruzeiro do Oeste (algodão $60 \%$, café $21 \%$, soja $13 \%$ ). ${ }^{330}$ Os focos do empreendimento da CAC são as áreas com uma forte concentração de cultivadores com ascendência japonesa. Por parte dos produtores lusobrasileiros ocorre com frequência uma postura de distanciamento em relação à CAC, que é chamada de 'japonesa', sobretudo em círculos nacionalistas. O verdadeiro motivo, contudo, é a rejeição da influência da cooperativa sobre a direção do empreendimento e a seleção dos produtos do cultivo, que em geral desconsidera o elemento especulativo.

Enquanto a estrutura dos produtos agrícolas negociados na área total de alcance da cooperativa apresenta participações individuais relativamente equilibradas, com uma forte diversificação - em que apenas a batata e o ovo aparecem com mais força - , no Norte do Paraná a oeste do Tibagi pode ser apontada uma concentração mais forte em alguns produtos principais. Isso mostra que uma policultura agrícola preparada para o mercado ainda é pouco difundida. Apesar do surgimento de cooperativas de produção de café especializadas na parte norte do Paraná, o café ocupa, com $28 \%$ de participação nos rendimentos, o máximo entre os produtos comercializados pelos membros da CAC. A produção

330 Segundo alguns levantamentos do Autor feitos em 1970 nos depósitos, dados sobre 1969. 
de ovos teve um crescimento especial, que claramente supera, com $24 \%$, a participação média no total $(17 \%)$. Algodão (16\%) e soja (14\%), bem como rami (6\%), ocupam os próximos lugares segundo sua importância no Norte do Paraná, enquanto a batata e o tomate não têm importância alguma (Tabela 43).

Devido à grande distância em relação ao centro comercial de São Paulo, frutas e legumes têm apenas uma reduzida importância regional. A grande produção de ovos, por outro lado, deve ser considerada em relação com a utilização do esterco de galinha na fertilização das plantações de café. Neste caso especial, rompe-se a organização espacial do cultivo dos membros da cooperativa, que é direcionada diretamente para a Metrópole de São Paulo no esquema dos anéis de Thünen, de acordo com a perecibilidade dos produtos.

Ao todo, a participação do Norte Novo e do Norte Novíssimo do Paraná no total das receitas da 'Cotia' é de aproximadamente $11 \%$ e ainda é capaz de crescer significativamente.

Contrapõe-se, contudo, à expansão da diversificação agrícola e a uma intensificação do cultivo de produtos agrícolas anuais a tendência para a criação de gado, que se manifesta na mudança estrutural dos grandes empreendimentos, na ampliação das áreas de empreendimentos médios maiores através da aquisição propriedades menores e na expansão das áreas de pastagem através da instalação de pastagens de arroteamento nas florestas remanescentes às margens do Paranapanema e do Paraná.

\section{b) Desenvolvimento da pecuária}

A diminuição das áreas de cultivo de café em vales ameaçados por geada, os problemas no cultivo de produtos agrícolas anuais de trabalho intensivo, as condições da nova legislação social da terra, a queda da produtividade natural no cultivo desprovido de fertilizantes em solos desgastados e a conjuntura favorável do mercado de carnes fizeram que a criação de gado se desenvolvesse extraordinariamente no Norte do Paraná na última década.

Além das mudanças internas aos empreendimentos, como a ampliação das áreas de pastagens para a criação de gado leiteiro no caso de propriedades cafeeiras de tamanho pequeno e médio localizadas próximas a cidades, os empreendimentos médios maiores e os empreendimentos grandes transferiram o foco econômico para a criação de gado ou mudaram de fazenda de tipo misto exclusivamente para a criação ou para a engorda de gado.

A forte tendência iniciada no começo dos anos 1960 para o estabelecimento de pastagens artificiais fez que as reservas de florestas úmidas tropicais, que então ainda eram significativas no Norte Novíssimo, se transformassem em pastagens de arroteamento (Foto 16). Esse processo foi raramente realizado de maneira direta, mas - como mencionado - passava principalmente por um estágio intermediário de cultivo plurianual de grãos e leguminosas, plantas oleaginosas e fibrosas.

Enquanto a quantidade de cabeças de gado se multiplicou quase quatro vezes de 1950 a 1960, passando de 177.000 para 673.000 cabeças, de 1960 a 1967 ocorreu um acréscimo de 158\%, ultrapassandos-se, com isso, a cifra de 1 milhão. Infelizmente não estão disponíveis dados estatísticos mais atuais, no momento de conclusão desta pesquisa. ${ }^{331}$ No entanto, pode-se concluir, a partir de comunicados da Secretaria de Agricultura do Paraná, da Acarpa e de informações sobre as tendências de municípios particulares, que a quantidade de cabeças de gado da região pesquisada chega neste momento a cerca de 2,5 milhões.

O maior crescimento na criação de gado ocorreu devido às crises no cultivo de café e em consequência dos solos arenosos pouco apropriados para a agricultura no Norte Novíssimo, principalmente ao norte do Ivaí, no extremo noroeste do Paraná (Mapa 42). Nos anos 1950, paulistas da região de Alta Sorocabana se estabeleceram lá com a intenção de realizar criação extensiva de gado. Depois de aproximadamente uma década eles atingiram sua meta econômica. Poucos ainda residem na região, principalmente em Loanda, o centro dos mercados agropecuários e das exposições. A maioria vive em Maringá ou Londrina ou retornou para o estado de São Paulo (entre outras cidades, para Presidente Prudente) e confiaram os empreendimentos a administradores.

331 Segundo o Censo Agrícola 1960 do Estado do Paraná (Sinopse preliminar), a parcela dos empreendimentos dedicados à pecuária, com relação ao total dos empreendimentos agrícolas na região em estudo, compreendia $40 \%$, e a quantidade média de cabeças de gado por empreendimento era de 16 . Apenas 2,3\% dos empreendimentos com pecuária possuíam mais de 100 cabeças de gado (parcela de $44 \%$ da quantidade total de cabeças!) A capacidade de suporte média anual girava em torno de 1,2 cabeças por hectare. 
Tabela 44: Desenvolvimento da pecuária no Norte Novo e Norte Novíssimo do Paraná entre 1960 e 1967

\begin{tabular}{|l|c|c|c|}
\hline Região & 1960 & 1967 & Aumento entre 1960 e 1967 (em \%) \\
\hline Londrina & 258.000 & 395.000 & 53 \\
\hline Maringá & 65.000 & 168.000 & 158 \\
\hline Apucarana & 77.000 & 148.000 & 92 \\
\hline Norte Novo & 400.000 & 711.000 & 345 \\
\hline Paranavaí & 133.000 & 592.000 & 322 \\
\hline Umuarama & 71.000 & 300.000 & 91 \\
\hline Campo Mourão & 69.000 & 132.000 & 275 \\
\hline Norte Novíssimo & 273.000 & 1.024 .000 & 158 \\
\hline Total & 673.000 & 1.735 .000 & 345 \\
\hline
\end{tabular}

Fonte: IBGE, Sinopse preliminar do Censo Agrícola de 1960, Estado do Paraná, e DEE Paraná, Animais existentes no Estado em 1967.

Em oposição às áreas de criação de gado do Paraná central e a leste, as pastagens do Norte do Paraná não são pastagens naturais dos 'Campos limpos', mas quase exclusivamente pastagens artificiais cujas áreas foram fortemente ampliadas na última década (Figuras 9-11). Tanto as raças bovinas quanto as pastagens do norte tropical do Paraná são diferentes das outras regiões do Estado, um sinal da clara mudança climática nos planaltos ao sul da região em estudo.

Enquanto nos 'Campos' e nas pastagens plantadas recentemente com pasto jesuíta (Paspalum platycaulon), que é resistente ao frio, em Guarapuava no Paraná central, pastam principalmente as raças bovinas europeias (Charolês, Hereford, Holstein, Friesen) e gado mestiço, no norte dominam raças de Zebu e pastagens tropicais de origem africana ricas em nutrientes, principalmente o pasto de guiné (Panicum maximum), chamado no Brasil de capim colonial. ${ }^{332}$ Além disso, também é crescentemente plantado capim de pangola (Digitaria decumbens) ${ }^{333}$, que se recupera mais rapidamente das geadas. Mas também cresce a importância do capim kikuyu (Pennisetum clandestinum) e capim-elefante e napier (Pennisetum purpureum), ambos naturais da zona de tierra fria na África Oriental e conhecidos há cerca de 50 anos no Brasil devido a sua baixa sensibilidade à geada, nas regiões do Norte do Paraná que recentemente foram diversas vezes atingidas por geadas.

A criação de gado leiteiro é limitada às terras em torno de cidades maiores como Londrina, Apucarana, Maringá e Paranavaí, onde alguns empreendimentos medianos se especializaram com sucesso na reprodução de linhagens leiteiras das variedades de Zebu Guzerat e Gir. ${ }^{334}$

O foco da pecuária no Norte do Paraná está na criação de gado de corte. Aqui domina o gado Zebu, que foi trazido da Índia para o Brasil no começo do século XX, até que a peste bovina causou a proibição total de importação, a qual só foi parcialmente suspensa depois do estabelecimento de uma estação de quarentena na Ilha de Fernando de Noronha, sob rígido controle governamental.

A criação paranaense de Zebu obteve impulsos extraordinários através de iniciativas de alguns criadores. Assim, criadores residentes em Londrina estabeleceram contato direto com um conhecido criador indiano de Zebu e importaram em 1959 mais de 100 animais de reprodução para o Paraná, burlando a proibição de importação através da Guiana Francesa. Em um acordo com o secretário de agricultura paranaense e posterior governador Pimentel, os animais importados da Índia serviram

332 Sobre a questão da introdução de variedades africanas de capim na América do Sul, cf. Parsons (1970). Assim, p. ex. o capimgordura (Melinis minutiflora) e o pasto jaraguá (Hyparrhenia rufa), que Schmidt e Marcus (1943) ainda consideravam nativas do Brasil, chegaram ao Brasil vindos de Angola provavelmente já no séc. XVIII em navios-negreiros como palha dos dormitórios.

333 Capim pangola e kikuyu se espalham exclusivamente por ramificações ou por mudas, uma vez que não produzem sementes, enquanto o capim da guiné é espalhado por semeadura ou por mudas (PARSONS, 1970, p. 145 e 151).

334 Cruzamentos entre Holsteins puros e Zebu-Girs puros foram uma fase transitória para a pecuária leiteira de Girs, que, contudo, atualmente ainda se encontra num estágio inicial (NIXDORF, 1967, p. 59/69). 
como base para a criação de Zebu de raça pura no Paraná e substituíram os animais de reprodução qualitativamente piores de até então, um experimento que foi citado pela FAO como modelo para projetos semelhantes na América Latina. ${ }^{335}$

As variedades de Zebu Gir, Guzerat e Nelore (na Índia: Ongole) são extremamente apropriadas para o clima das margens tropicais do Norte do Paraná, são especialmente resistentes a doenças e suportam a piora das pastagens no inverno melhor do que o gado brasileiro mestiço (CODEPAR, 1964a, I, p. 59ss.). Além da criação de gado das variantes zebu, também foi realizado um cruzamento de Gir com Guzerat, que foi chamado de Indubrasil, tendo atualmente, após um sucesso inicial, uma importância reduzida entre os criadores. ${ }^{336}$

Na pecuária extensiva do Norte do Paraná, impôs-se o Nelore, que é mais frugal do que o Gir e, ao contrário deste, vai à procura de pasto também em caso de pastagens de arroteamento cobertas desuniformemente com capim (Fotos 15 e 16); por outro lado, os bezerros jovens de Nelore são mais independentes no recebimento de alimentação e mais resistentes. Em contrapartida, de acordo com a experiência dos criadores, o gado Nelore não é tão manso quanto o Gir.

O gado Santa Gertrudis, um produto de criação de raça de corte do famoso King Ranch, no Texas ${ }^{337}$, foi trazido dos EUA no final dos anos 1950. Ele matura cedo e combina a alta produtividade de raças europeias com a resistência no caso de más condições de pastagem. Os resultados da criação na região de Alta Sorocabana foram bons. De lá também foi vendido o Santa Gertrudis para o Norte do Paraná, onde ele se adequa principalmente para empreendimentos explorados de maneira intensiva, os quais, aliás, são representados apenas em pequena medida (entre outros, em Rolândia).

Pode-se distinguir três fases de desenvolvimento da pecuária no Norte do Paraná:

1. O ponto de partida foi uma pecuária reduzida no fundo do vale dos sítios de cultivo de café e fazendas, para o abastecimento próprio dos empreendimentos com leite e carne. Quando a capacidade de suporte atingia dois bois por hectare, os animais mais velhos eram vendidos para evitar que se excedesse essa capacidade.

2. A segunda fase desenvolveu-se na região em estudo principalmente desde o início dos anos 1960 com o tipo de empreendimento café-gado já conhecido em São Paulo em grandes propriedades (geralmente acima de 250 hectares). Essas fazendas mistas localizam-se tanto no Norte Novo quanto no Norte Novíssimo. Além da plantação de café, que em geral constitui o foco econômico, é realizada a engorda de gado. Em anos com queda das colheitas de café devido a geadas, a venda dos bois prontos para o abate para abatedouros regionais ou localizados em São Paulo garantem financeiramente o empreendimento.

3. Se a segunda fase já revela transições graduais para a pecuária como foco principal, a terceira fase é determinada pela especialização em criação ou engorda de gado. Participam deste desenvolvimento tanto empreendimentos grandes quanto médios.

Além da sequência temporal destas três fases de desenvolvimento dentro das regiões, essas fases também ocorrem paralelamente no espaço. Enquanto os empreendimentos café-gado se mantêm principalmente no Norte Novo e na região de transição para os solos arenosos do Norte Novíssimo, os empreendimentos exclusivos de pecuária se concentram na parte norte do Norte Novíssimo, principalmente ao norte do Ivaí e no vale do Paranapanema. Este desenvolvimento é condicionado pelo esgotamento da produtividade do solo, destruição dos cafezais pelas geadas e pela crescente erosão do solo na região do arenito Caiuá. A transição da plantação de café para a pastagem ocorre em empreendimentos pequenos e médios, especialmente através da fase intermediária de cultivo de algodão ou milho, ou arroz, dependendo da situação dos preços. Em seguida é semeado o capim entre os pés de café (maio). Em agosto, o capim e os cafeeiros são queimados superficialmente. Se os cafeeiros secos e danificados pela geada não tiveram queimado completamente, eles são cortados em parte dos empreendimentos para evitar que o gado se machuque. No caso dos grandes empreendimentos, os

335 Cf. Realidade (São Paulo), 5, 52, julho de 1970, p. 66.

336 De acordo com a opinião de Nixdorf (1967, p. 62), a Indubrasil ainda não tinha se fixado suficientemente como nova raça, e logo houve segregações em larga escala.

337 Cruzamento de shorthorn (5/8) e brahman (3/8), um zebu brastante próspero há décadas nos estados do sul dos EUA. Faz mais de 50 anos que o gado Santa Gertrudis tem muito sucesso nos EUA e atualmente está difundido em 30 estados dos EUA, bem como em 33 outros países (WEBSTER e WILSON, 1969, p. 442). 
cafeeiros danificados pela geada ou com baixa produtividade são arrancados com o trator, a terra é arada e em seguida ocorre a semeadura com capins de pastagem.

Figura 12: Rotação das pastagens na Fazenda Paranapanema (município de Inajá)

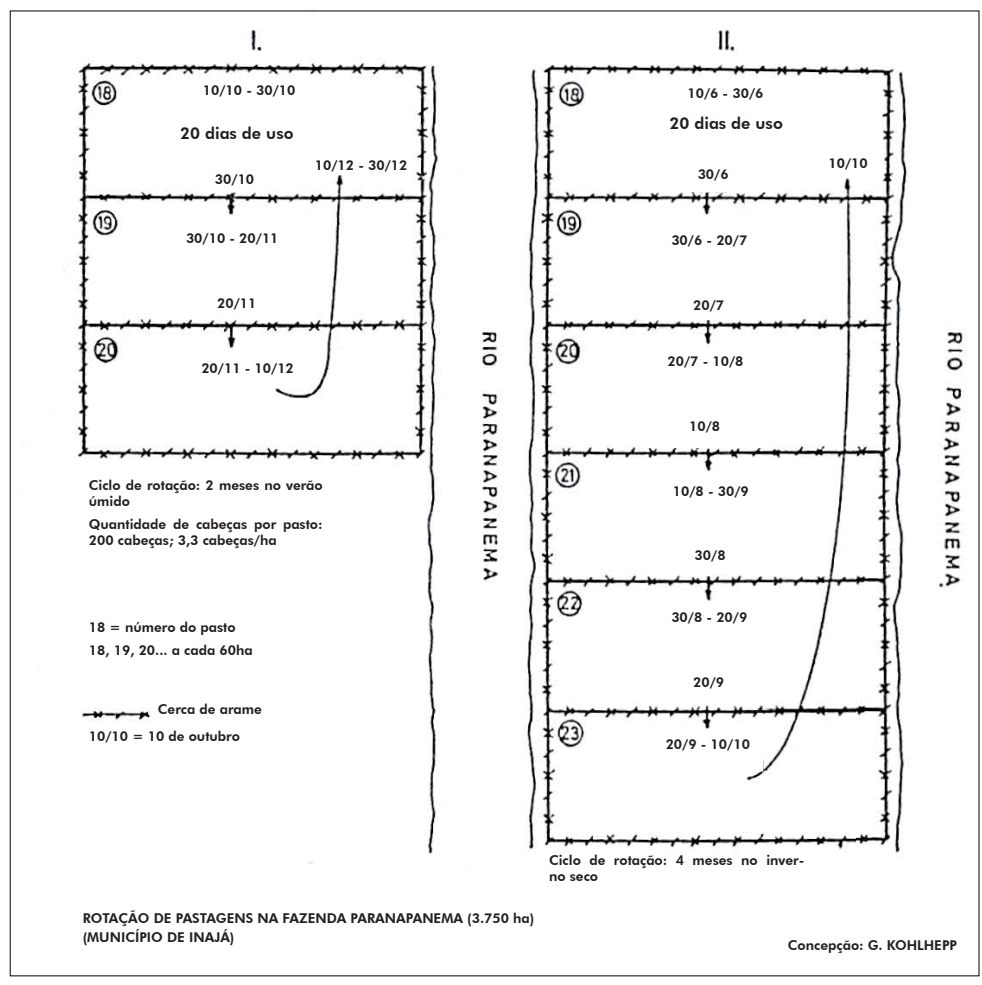

Com exceção de um número relativamente reduzido de fazendas-modelo de grandes empresas e de criadores apaixonados de grande capital, a pecuária de gado de corte encontra-se ainda em um estágio bastante primitivo. Em vários empreendimentos as pastagens não são subdivididas - em geral por causa dos custos com arame, postes e mão de obra -, de maneira que o gado sofre grandes perdas de peso devido a longos percursos e torna-se impossível sua seleção por grupos de idade e diversas categorias. No caso de encostas apenas levemente descendentes dos amplos espigões da região a oeste do Paranavaí, os animais precisam percorrer longas distâncias até o curso de água. No caso de subdivisão da pastagem, faz-se necessária a instalação de poços com profundidade média de $50 \mathrm{~m}$ à meia altura, para assegurar o abastecimento de água para o gado.

Ainda é rara a rotação de pastagens com frequência regulada de manejo e povoamento temporário de partes individuais de pastagens para a regeneração do capim. Assim, por exemplo, na Fazenda Paranapanema, no município de Inajá (Figura 12) é realizado no verão úmido um ciclo rotacional de dois meses com três partes de pastagem de 60 hectares respectivamente. Cerca de 200 cabeças de gado pastam por 20 dias nas pastagens cobertas com Panicum maximum e passam então para o próximo pasto. No inverno seco, a rotação é estendida para seis partes de pastagem para a regeneração das pastagens e é, com isso, elevada para quatro meses. No caso de vacas e bezerros, a mudança é feita já após 14 dias devido ao rápido esgotamento do capim.

Ainda não se estabeleceu no Norte Novo e Norte Novíssimo uma clara organização espacial nas formas de empreendimento de criação de gado. Há empreendimentos com criação própria, aquisição e engorda de touros e bezerros, bem como empreendimentos puros de engorda de gado já amadurecido, com um grau de especialização mais ou menos alto. Ao lado desses, há também os empreendimentos que operam no esquema tradicional e criam os próprios animais até a idade de abate. 
Observando-se a distribuição espacial das formas de empreendimento de criação de gado, pode-se estabelecer um primeiro critério da organização espacial no caso dos empreendimentos de engorda. Estes começam a se concentrar ao longo do Rio Paranapanema e Paraná, no norte e no oeste da região em estudo. Os motivos disso são a alta produtividade das pastagens de engorda ('invernadas'), por conta dos poucos danos causados pelo frio no inverno, bem como a localização desta zona, na região de influência direta dos grandes abatedouros do oeste de São Paulo.

A Cia. Melhoramentos Norte do Paraná quer estabelecer todos os seus empreendimentos de criação ao sul do Ivaí, entre outras cidades, em Cianorte (Fazenda Lagoa e Água do Indío, entre outras). Os touros jovens serão então engordados em fazendas próprias próximas ao Paranapanema. No entanto, a divisão interna do empreendimento ainda não foi completamente realizada. Em 1961, o efetivo de cabeças de gado da sociedade estava em 2.500, em 1965 em cerca de 11.000, ao final de 1970 em cerca de 26.500, devendo ser sistematicamente ampliado até 50.000.

30 a 50\% dos bois magros localizados nas pastagens de engorda no Norte do Paraná vêm das regiões de criação do centro e do oeste do Mato Grosso do Sul (entre outros, do Pantanal). Eles têm entre $21 / 2$ e 3 anos de idade e, após a condução durante semanas, são engordados durante 8 a 12 meses, ganhando então de 60 a $90 \mathrm{~kg}$ de peso. O gado Nelore se destaca pelo ganho mais acelerado de peso em relação ao Gir (CODEPAR, 1964, I, p. 83). Pesando entre 250 e 300 kg, os bois são então vendidos para grandes abatedouros regionais (Paranavaí, Maringá, Londrina) ou para São Paulo. O transporte a partir das invernações próximas ao Rio Paraná até São Paulo é feito com embarcações de transporte de gado (com capacidade para até 400 animais), partindo dos pequenos portos de embarque em Porto Camargo, Querência, Brasílio, Porto Rico ou São José até o grande porto fluvial paulista em Presidente Epitácio, no Rio Paraná, o ponto final da Ferrovia Sorocabana, de onde a distribuição para os abatedouros ocorre por trem ou caminhão.

Alguns dos empreendimentos paranaenses de engorda estabeleceram novas pastagens de arroteamento no sul do Mato Grosso, aumentando com isso as suas áreas de operação. Criadores de gado do Paraná também possuem fazendas de criação no Mato Grosso do Sul.

Os estabelecimentos de criação intermediária compram bezerros com idade entre 1 e 11/2 ano de criadores com menos capital, criam-nos até cerca de 14 a 18 meses de idade e então vendem os bois para os empreendimentos de engorda (NIXDORF, 1967, p. 61).

Estão entre os maiores empreendimentos com engorda de gado no Norte do Paraná as Fazendas Paranapanema (3.750 ha) e Guanabara (6900 ha), ambas localizadas à margem do Rio Paranapanema. A primeira é um puro empreendimento de engorda, sendo $67 \%$ da área do empreendimento pastagens de colonião e $27 \%$ de floresta, que atualmente está sendo derrubada. A fazenda Guanabara foi adquirida somente mais tarde por diversos proprietários e unificada com uma parte de terra devoluta da companhia de colonização (Mapa 43). Embora mais de 75\% da área do empreendimento seja coberta por pastagens artificiais, o empreendimento também possui em suas localizações mais elevadas uma plantação de café recente ${ }^{338}$, cultivada de acordo com as perspectivas mais modernas, com 106.000 cafeeiros (1970), que devem ser ampliados até 500.000. As florestas tropicais úmidas à margem do Rio Paranapanema foram quase totalmente destruídas pelas queimadas. As pastagens de colonião foram implementadas na ghost-forest, que, com suas ruínas de árvores carbonizadas, compreende amplas partes da fazenda. O estabelecimento das pastagens de rotação ainda está em curso. Em parte, as cercas não são mais providas de arame farpado, mas de arame de aço liso (ao todo $235 \mathrm{~km}$ ), para evitar o risco de ferimento e infecção do gado. A área dos pastos individuais varia entre 31 e 163 hectares, e é em média de 95 hectares. O tempo de manejo transcorre de acordo com a Figura 12, com uma capacidade de suporte de 3 animais por hectare. Para cada 400 cabeças de gado é necessário apenas um trabalhador. Para o abastecimento ininterrupto de água foram construídas barragens e bebedouros para o gado, assim como dois poços, a partir dos quais parte respectivamente uma tubulação de água com diversos quilômetros de extensão. $\mathrm{O}$ gado é vacinado contra brucelose, febre aftosa e esplenite. Em 1970, a idade média dos animais vendidos aos abatedouros era de 3 anos e 4 meses, o peso de $260 \mathrm{~kg}$.

É especialmente importante na engorda de gado que as pastagens não sejam superpovoadas (Fazenda Guanabara e Paranapanema $\varnothing 1,9 /$ ha/ano) e que o gado tenha sal à disposição. Muito raramente o gado recebe nos meses de inverno, de junho a agosto, cana de açúcar picada e milho triturado como alimentação.

338 A plantação de café dos proprietários anteriores caiu vítima da 'erradicação'. 
A fábrica de açúcar em Porecatu montou um celeiro com cana de açúcar desfibrada (15 kg/ animal/dia), bolo de algodão, melaço, milho moído e sal mineral (4 kg/dia), que proporciona que, dentro de alguns meses, os bois de $2 \frac{1}{2}$ anos comprados atinjam um ganho de peso de 100-140 $\mathrm{kg}$ ! A meta do projeto é a engorda de 30.000 bois/ano! Essa iniciativa pioneira dá perspectivas totalmente novas à engorda de gado, pois com ela alcança-se pela primeira vez uma idade de abate e peso ideais.

Oferecem-se no Norte do Paraná boas possibilidades de desenvolvimento à criação e à engorda de gado: o satisfatório estado de saúde do gado; a capacidade de suporte relativamente alta das pastagens (que não se degradam, como em São Paulo, quando há uma seca prolongada); e, com a crescente demanda por carne, a ampliação de mercados locais e regionais, bem como o estabelecimento de uma rede de abatedouros.

Mas ainda prepondera entre muitos criadores de gado a mentalidade puramente extrativa, à maneira dos pioneiros. Rotação de pastagens, ração ou mesmo ensilagem, bem como instalações para o controle do gado, são amplamente desconhecidos. Poucos criadores de gado possuem os necessários conhecimentos fundamentais. Muitos dos empreendimentos médios precisam vender os bezerros crescidos a criadores intermediários por falta de pastagem. Os empreendimentos extensivos de engorda trabalham com um volume de trabalho muito pequeno e um risco muito baixo, com ganhos elevados. Atualmente, a engorda de gado é objeto da especulação dos grandes proprietários, que pretendem ampliar suas áreas de pastagem por meio de novas compras ${ }^{339}$. Ao invés de utilizar o crédito dos bancos paranaenses e do Banco do Brasil para a melhoria dos rebanhos através de seleção, para o cercamento das pastagens, para construir barragens e poços ou para a alimentação no inverno, uma grande parte do crédito é usada apenas para a aquisição de bois magros, ou seja, para a ampliação dos rebanhos.

As transformações estruturais na geografia agrária e a forte concentração com variação regional sobre a criação de gado de trabalho extensivo causaram na década passada consideráveis transformações geográficas e migrações populacionais no Norte Novo e Norte Novíssimo.

\section{ORGANIZAÇÃO ESPACIAL DAS TRANSFORMAÇÕES POPULACIONAIS}

O forte aumento populacional, que foi característico do Norte do Paraná até 1960 e que resultou de uma migração interna, ligada ao boom do cultivo de café, com origem no interior de São Paulo, prosseguiu entre 1960 e 1970 apenas nas partes do oeste e do sul da região pesquisada, sobretudo ao sul do Ivaí, com a colonização dos remanescentes de floresta.

Contrapõe-se ao alto crescimento da população urbana ${ }^{340}$ em todas as partes do Norte Novo e Norte Novíssimo (valores regionais entre 84 e 438\%, Tabela 12 , p. 305, Anexo) um aumento muito pequeno da população rural no Norte Novo $(7 \%$ ), assim como um aumento maior no Norte Novíssimo $(74 \%)$. Observando-se as regiões individuais, constata-se entre 1960 e 1970 um retrocesso de 16, 15 e 4\% na população rural na região de Paranavaí, Londrina e Maringá. Trata-se aqui parcialmente de êxodo rural e migração para a cidade grande mais próxima ou para a sede do município, mas também parcialmente de uma migração para as regiões de colonização mais recentes nos arredores de Umuarama.

O Mapa 44 oferece uma diferenciação da transformação absoluta e relativa da população urbana, da população rural e da população total em base municipal. Mostra-se com isso uma clara organização espacial das transformações populacionais. A diminuição da população rural, que, no geral, também está ligada à diminuição da população total do município, ocorreu de 1960 a 1970 quase que exclusivamente ao norte do Ivaí. Atingiram-se perdas populacionais superiores a 60\% em Nova Aliança do Ivaí (74\%),

339 Os preços médios de terra por alqueire paulista (2,42 ha), em agosto de 1970 na região do arenito Caiuá, compreendiam Cr $\$ 1.500,00-2.000,00$ para floresta, Cr $\$ 2.000,00$ para pastagem e Cr\$2.500,00 para área de lavoura (algodão). Sobre 'terra roxa', a terra utilizada para produtos agrícolas de um ano, $\mathrm{Cr} \$ 3.000,00-4.000,00$, e a terra para pastagem $\mathrm{Cr} \$ 3.000,00$ (dados de diferentes agrônomos da Acarpa).

340 Compreende-se 'população urbana', segundo a estatística populacional brasileira, como os habitantes das cidades principais dos municípios e das sedes distritais. 
Mirador, Presidente Castelo Branco e Inajá. As pequenas localidades municipais insignificantes ao norte do Norte Novo de Londrina (Guaraci, Miraselva, Iguaraçú, Itaguajé, Centenário do Sul etc.) também sofreram perdas populacionais nesse período.

As taxas de crescimento mais significativas ocorrem entre o Ivaí e o Piquiri, bem como ao sul do Piquiri, na região do extremo avanço populacional riograndense, com valores de $100 \%$ e, em parte, acima de $300 \%$. Em contraste com a discrepância do desenvolvimento da população urbana e rural no Norte Novo e na região de Paranavaí, nas regiões pioneiras em torno de Umuarama, Goio-Erê, Xambrê, Iporã etc., as taxas de crescimento da população rural e das localidades municipais em estágio pioneiro são igualmente altas.

Ao se interpretar o aumento populacional no Noroeste (Diamante do Norte, Marilena, Porto Rico, Santa Izabel do Ivaí etc., Mapa 44), deve-se mencionar que este ocorreu sobretudo até 1965/1966, sofrendo então uma leve perda populacional. O turno de 10 anos do censo populacional entre 1960 e 1970 só pode apreender o valor médio para essa década, mas não a oscilação durante esse período. Isso significa que, em parte, a tendência de despovoamento também já se estabeleceu nas regiões que, no centro, apresentam ainda um pequeno aumento populacional entre 1960/1970.

A representação da transformação da população rural em relação ao crescimento natural torna mais clara a tendência evolutiva geral (Mapa 45) ${ }^{341}$. A mais forte evasão da população rural pode ser constatada no norte central da região pesquisada, onde a economia de pastagem sobre solo arenoso se desenvolveu como fator econômico dominante e numerosos trabalhadores rurais perderam o trabalho. As localidades municipais possuem - se é que possuem - apenas uma pequena capacidade de recepção; em geral, no entanto, elas também apresentam evasão.

Ao redor dessa região com migração iniciada já no começo dos anos 60 fecha-se, em forma de semicírculo, uma estreita zona de transição com perda populacional relativa, ou seja, com fraca evasão. Esta compreende, no Norte Novo, municípios em que a área de cultivo de café foi diminuída no âmbito dos programas de erradicação e em que as cidades grandes absorveram muitos dos colonos despedidos. Estão entre elas regiões no Norte Novíssimo em que as áreas de pastagem foram ampliadas depois da última geada, iniciando-se só então a migração dos trabalhadores rurais. Por outro lado, em torno de Loanda a parcela das áreas de pastagem já era significativa em 1960, de modo que até 1970 apenas pôde ocorrer uma perda populacional relativamente pequena.

À zona de transição segue-se um anel externo com uma imigração forte ou muito forte, que inclui no oeste as zonas pioneiras e no sul a zona da margem tropical. Enquanto essa imigração entre o Ivaí e o Piquiri ainda está ligada ao avanço extremo do sudoeste da fase final da colonização do café, as florestas úmidas subtropicais e florestas de araucárias remanescentes na fronteira sul ameaçada por geada da região em estudo foram utilizadas na forma da primitiva rotação da terra, isoladas do boom do café. Apenas na região de Jardim Alegre e Ivaiporã o cultivo de café foi responsável por uma imigração mais forte (Mapas 44 e 45).

As direções de migração regionais principais da população rural ocorrem do nordeste para o sudoeste. A migração suprarregional direcionada a regiões rurais da área pesquisada ocorre para o noroeste na direção do sul do Mato Grosso (Dourados), bem como, em casos isolados, em ocupações de fazendeiros paranaenses no norte de Mato Grosso.

Os projetos de exploração na Amazônia, com sua grande ressonância em todas as partes do Brasil, levou, já no início dos anos 1970, alguns grupos de trabalhadores rurais desempregados e meeiros a se assentarem em Altamira no Estado do Pará. Em julho de 1970, um grupo de 226 pessoas (38 famílias) abandonou o município de Tapira (Norte Novíssimo, ao sul do Ivaí), para se assentar em terra própria na região de colonização do Incra (Instituto Nacional de Colonização e Reforma Agrária), em Altamira,

341 No Mapa 45, o crescimento natural (1960-1970: 29,7\%, ou seja, uma taxa de crescimento de algo mais de 26 para cada 1.000 habitantes por ano) é marcado com o valor-índice ' 1 '. Se o crescimento absoluto da população está acima desse valor, então ocorre uma migração $(>1)$. No caso de um crescimento menor que o crescimento natural $(<1)$, ocorreu uma perda relativa de população, ou seja, iniciou-se uma evasão perceptível. Valores negativos no Mapa 45 indicam que a evasão supera o crescimento populacional natural. 
à margem da estrada transamazônica, que estava em construção. ${ }^{342}$ No entanto, já foi iniciada nesse ínterim uma migração de retorno de colonos insatisfeitos. ${ }^{343}$

O êxodo da população rural, que até hoje aumentou ainda mais, foi causado pela mudança em grandes áreas para a criação extensiva de gado. As causas foram os fortes danos por erosão nas plantações de café da região de arenito, o fim do boom do café, assim como os danos causados pela geada.

O ditado brasileiro 'onde entra casco de boi, sai pé do homem' é certeiro em relação às consequências da ampliação das pastagens. Com o retrocesso da economia do café também cessou o desenvolvimento dinâmico dos pequenos subcentros regionais. Isso deve ser mostrado através do exemplo da sede do município de Inajá, a nordeste de Paranavaí (Mapa 46): a colonização conduzida por particulares começou no auge do cultivo de café em 1954/1955. O patrimônio de 69 hectares estabelecido pela companhia de colonização foi elevado em 1960 à sede de município. Na segunda metade dos anos 1950, foi vendida uma primeira grande parte dos 750 terrenos no local, surgindo um dos típicos locais pioneiros do frontier cafeeiro, com uma vida comercial ativa e certa medida de espírito especulativo.

Contudo, mal os cafeeiros haviam atingido a idade ideal de produção, a superprodução brasileira tornou necessária a redução dos cafezais. Além disso, surgiram em Irajá fortes danos causados nas plantações pela voçoroca (gully erosion). Em 1966/1967 - apesar da pouca idade - ,43\% do efetivo de pés de café do município de Inajá foram arrancados. À fase de transição para milho e algodão seguiu-se a mudança para as pastagens. Depois da geada de 1969, a área de cultivo de café continuou a diminuir em favor da área de pastagem. Atualmente, $82 \%$ da área do município é ocupada com pastagem, $8 \%$ com café, $5 \%$ com floresta, $4 \%$ com produtos agrícolas anuais, sendo o $1 \%$ restante ocupado com ruas, caminhos, área local etc.

A população rural do município retrocedeu de 1960 a 1970 em $63 \%$, a população total em $45 \%$. O desenvolvimento da localidade de Inajá, que no início dos anos 1960 vivenciou ainda uma forte imigração, estagnou. Em 1970, dos terrenos medidos no local, 62\% foram vendidos, e das datas vendidas, apenas $40 \%$ foram construídas. No momento do mapeamento (outubro de 1970) nenhum terreno fora vendido em 10 meses. $15 \%$ das moradias do local foram abandonadas, assim como quatro comércios, dois bares, um posto de gasolina e dois galpões (Mapa 46). Inajá conta ainda com cerca de 1.500 habitantes.

Enquanto a escola construída pela sociedade de colonização e um pequeno hospital ainda funcionam, o local não possui mais nenhuma filial de banco e só tem uma escassa pensão. As ordens iniciais de construir casas de alvenaria ao longo da rua principal foram canceladas. Muitos dos pequenos negócios estão próximos da ruína. Nenhuma rua é pavimentada, partes da planta da cidade estão abandonadass e lá pastam porcos e cavalos. Algumas quadras marginais foram aradas e serão utilizadas para a agricultura.

O destino do êxodo dos habitantes de Inajá é geralmente Paranavaí, o centro regional mais próximo. $70 \%$ da população rural que emigrou do município mudou-se para a região recém explorada de Goio-Erê (30\%), Umuarama, Xambrê, Pérola, Alto Piquiri, Iporã, assim como alguns se mudaram para a margem sul do Rio Piquiri (Formosa d'Oeste, Assis Chateaubriand etc.). Por outro lado, 20\% se assentaram como colonizadores da floresta nos municípios de Ivinheíma e Naviraí no sul do Mato Grosso. ${ }^{345} \mathrm{Na}$ zona rural de Inajá havia, em outubro de 1970, 330 casas desabitadas. Fenômenos semelhantes podem ser observados em muitas localidades municipais da região do arenito Caiuá.

A análise do balanço total das transformações populacionais entre 1960 e 1970 (Tabela 12, p. 305, Anexo) mostra entre o Rio Tibagi e o Rio Pirapó (Norte Novo de Londrina) apenas um aumento de 15\%, na região de Paranavaí até mesmo de apenas $8 \%$. Esses números baixos, que estão muito abaixo da taxa

342 A viagem se deu de ônibus até Belém, de lá pelo rio de barco ou por barcos da marinha até Altamira, às margens do Xingu. Os colonos recebiam 100ha de terra por família, casas de madeira e 6 meses de apoio financeiro, bem como sementes e algumas ferramentas. O acompanhamento médico devia ser garantido pelo Incra (Folha de Londrina, 23/07/1970).

343 Segundo questionários do Autor em julho/agosto de 1973 aplicadas na Transamazônica, no âmbito de investigações para o planejamento do desenvolvimento da Amazônia.

344 Uma grande fazenda (2.420 ha) na fronteira com o município Paranacity, que ocupava, até 1966, 350 famílias de agricultores com 1,1 milhões de cafeeiros, necessita de somente 3 famílias, depois da mudança total para a pecuária de engorda (com um total de 4 trabalhadores!)

345 Dados da prefeitura de Inajá. 
de crescimento natural, resultam - apesar do forte crescimento populacional das cidades - do elevado êxodo rural. No Norte Novo, o aumento populacional entre 1960 e 1970 estava no total em 33\% (1950/60: 132\%), no Norte Novíssimo em 96\% (1950/60: 963\%!) e desacelerou-se correspondentemente ao curso do desenvolvimento da colonização agrária com o avanço do frontier ao Rio Paraná. ${ }^{346}$

A densidade populacional média é no Norte Novo de 70 hab./ $\mathrm{km}^{2}$. A densidade populacional rural dessa região aumentou de 1960 até 1970 apenas de 39 para 41 (Tabela 7, p. 304, Anexo). No Norte Novíssimo, a densidade populacional total duplicou até 43 desde 1960; fora das cidades no centro, aumentou de 19 para 32; ao norte do Ivaí, no entanto, diminuiu de 26 para 22!

A densidade populacional rural ${ }^{347}$ revela na faixa da pequena e média propriedade no cultivo de café na terra roxa na região de colonização do CMNP e de algumas pequenas companhias privadas (Ivaiporã, Jardim Alegre, entre outros) valores elevados, acima de 50 hab./ $\mathrm{km}^{2}$ (vide Mapa 47). Ao sul da fronteira do arenito Caiuá na região do Piquiri, esses valores de densidade são atingidos em uma ramificação do cultivo de café próximo a Goio-Erê, mas também fora da região de café em solos férteis de argila vermelha na região agrária dos colonisadores riograndenses (ao sul do Piquiri). Em 1970, as regiões arenosas do Norte Novíssimo apresentaram, sobretudo entre o Ivaí e o Paranapanema (onde ocorreu a expansão principal da economia de pastagem), densidades populacionais rurais mais reduzidas do que a média paranaense $\left(23 \mathrm{hab} . / \mathrm{km}^{2}\right)$. Destaca-se claramente no nordeste a zona de plantação de açúcar e café utilizada de maneira extremamente intensiva nas propriedades de Lunardelli, em torno de Porecatu à margem do Paranapanema.

Ao sul de Campo Mourão, a densidade populacional rural é pequena na altitude, nas florestas de araucárias arroteadas e, em parte, também destruídas pelos incêndios florestais de 1963. Isso vale também para a área do perímetro de Faxinal, Marilândia e a parte sul do município de Londrina.

A comparação da densidade populacional em 1960 (Mapa 25) e 1970 (Mapa 48) mostra no Norte do Paraná o avanço da zona de adensamento $\left(>50 / \mathrm{km}^{2}\right.$ para oeste/sudoeste). Na primeira metade dos anos 1960, esse desenvolvimento entre Ivaí e Piquiri ainda era marcado pela expansão do café. Os maiores valores de densidade acima de $100 / \mathrm{km}^{2}$ são atingidos entre Londrina, Apucarana e Maringá sobre o espigão, o centro dos maiores assentamentos urbanos.

O norte peritropical do Paraná, em que somente na parte oeste do Tibagi vivem $43 \%$ (3 milhões) dos cerca de sete milhões de habitantes do estado em 1970, destaca-se nitidamente quanto à densidade populacional das zonas restantes (Mapa 48). O que permaneceu foi a abrupta transição N-S para o Paraná central e oriental com suas florestas de araucária arrasadas por posseiros, indústria e comércio de madeira, bem como regiões de pastagens naturais dos 'campos limpos'.

Isoladamente aparecem as concentrações populacionais de Curitiba e Ponta Grossa. Por outro lado, a densidade populacional no Sudoeste aumentou evidentemente e quase atinge, nos arredores de Toledo e Assis Chateaubriand, ao sul do Piquiri, os valores da região de cultivo de café.

Nas partes do Noroeste utilizadas há mais tempo, os solos arenosos esgotados devido às transformações estruturais agrárias descritas levaram ao esvaziamento das zonas rurais.

\section{IMPORTÂNCIA DO PLANTIO DE CAFÉ NO NORTE DO PARANÁ AO CONCLUIR-SE A PESQUISA}

\section{a) Posição econômica e produtividade}

Uma ideia da importância do plantio de café após o final dos programas oficiais de erradicação, porém antes da ocorrência de geada em 1969, se apresenta no Mapa 49 pela porcentagem dos

346 A mudança absoluta da população alcançou, tanto entre 1950 e 1960 quanto entre 1960 e 1970 no Norte Novíssimo, com 705.000 e 750.000, quase o mesmo valor (Tabela 12, p. 305, Anexo).

347 Critérios de delimitação no Mapa 47: densidade populacional média do Brasil: 11 hab/ km²; densidade populacional rural média: Paraná fora da região estudada, 17; Paraná total, 23; área estudada, 36 (ou seja, mais do que o dobro do restante do Paraná). 
empreendimentos com plantio de café em relação ao número total dos empreendimentos agrícolas, bem como pela porcentagem das áreas de cultivo de café na área municipal ${ }^{348}$.

A posição econômica predominante é ocupada pelo plantio de café no Norte Novo, onde este perfaz em média mais de dois terços, e em alguns municípios acima de $90 \%$ de todos os rendimentos agroeconômicos. Na região de terra roxa em Londrina e Maringá entre Pirapó e Tibagi, entre 40 e 89\% (Rolândia) dos empreendimentos agrários possuem plantações de café. Mas também na região de Cianorte ao sul do Ivaí atinge-se em parte mais de 70\%.

$\mathrm{Na}$ fração de área do plantio de café na área municipal, especialmente os valores acima de $25 \%$ refletem espaços naturais adequados em razão da qualidade do solo e da altitude; nas áreas principais de produção, a fração se encontra em torno de 37 e $50 \%$. Em alguns municípios menores, mais da metade da área total subsiste de plantações de café (no máximo: Presidente Castelo Branco, 71\%). Com o crescente risco de geada, reduz-se a importância do plantio de café tanto no número de empreendimentos como também na fração de área em direção sul.

Em 1968, a área em estudo possuía mais de 60.500 empreendimentos agrícolas com plantio de café, que com 975.000 ha atingiam uma fração de 35\% de toda a área brasileira de plantação de café $^{349}$. Por volta de dois quintos de todos os empreendimentos tinham plantação de café, na parte norte até mesmo mais da metade. Após a geada de 1969, reduziu-se em torno de $4 \%$ o número de empreendimentos de plantação de café no Paraná até 1970, segundo primeiras estimativas do IBC, ou seja, por volta de 2.400 empreendimentos abandonaram totalmente o plantio de café. A diminuição da área de cultivo de 1969 a 1970 perfaz, entretanto, quase $10 \%{ }^{350}$, de forma que na área em estudo ainda existem por volta de 880.000 ha com café. Essas recentes modificações - como já citado - ocorrem, sobretudo, no Norte Novíssimo de Paranavaí bem como nas áreas marginais meridionais do Norte do Paraná (Figuras 9 a 11).

Tabela 45: Quantidade de empreendimentos com plantações de café e área de cultivo de café no Norte Novo e Novíssimo do Paraná em 1968

\begin{tabular}{|l|c|c|c|c|c|}
\hline & $\begin{array}{c}\text { Empreendimentos } \\
\text { com plantação de } \\
\text { café }\end{array}$ & $\begin{array}{c}\text { Fração no número } \\
\text { total dos empreen- } \\
\text { dimentos agrários } \\
\text { (em \%) }\end{array}$ & $\begin{array}{c}\text { Cafeeiros } \\
\text { (em milhões) }\end{array}$ & $\begin{array}{c}\text { Área de plantio } \\
\text { de café } \\
\text { (em 1.000 ha) }\end{array}$ & $\begin{array}{c}\text { Fração de área de } \\
\text { plantio de café na } \\
\text { área municipal } \\
\text { (em \%) }\end{array}$ \\
\hline $\begin{array}{l}\text { Londrina } \\
\text { Maringá }\end{array}$ & 12.161 & 53 & 202,8 & 282,6 & 28 \\
Apucarana & 7.915 & 52 & 90,3 & 126,0 & 34 \\
\hline Norte Novo & 9.439 & 36 & 76,1 & 108,4 & 15 \\
\hline Paranavaí & 29.515 & 46 & 369,2 & 517,0 & 25 \\
\hline Umuarama & 8.455 & 46 & 121,8 & 170,0 & 17 \\
Campo Mourão & 4.450 & 20 & 157,2 & 219,9 & 16 \\
\hline Norte Novíssimo & 31.029 & 35 & 46,4 & 68,3 & 5,5 \\
\hline Total & 60.544 & 39 & 325,4 & 458,2 & 12,5 \\
\hline
\end{tabular}

Fonte: Resumo próprio segundo dados do IBC, Agência Curitiba; cálculo da área de cultivo segundo valor médio de 720 cafeeiros/ha.

348 Os mais recentes dados sobre a quantidade dos empreendimentos plantadores de café bem como sobre a quantidade de árvores de café existem para os anos de 1967/68. O cálculo sobre a área de plantio de café correspondente foi feito com base no valor médio de 720 cafeeiros/ha. Em razão da falta de dados estatísticos sobre o uso da terra ou a área de atividade, a relação foi tirada da área de plantio de café pela área do município (Mapa 49). Dados: Agências do IBC em Curitiba, Londrina e Maringá.

349 83\% da área de plantação de café do Paraná se localiza no Norte Novo e Norte Novíssimo.

350 IBC, Anuário Estatístico do Café, 1968/70. 
Contudo, no ano de 1972, a fração do norte do Paraná a oeste do rio Tibagi em relação ao efetivo de pés de café do Brasil ainda estava em 35\% (= 850 milhões de cafeeiros). A porcentagem paranaense da produção assumiu novamente no ano de 1971, após a baixa de 1970, a posição dominante na produção brasileira de café (Figura 2) ${ }^{351}$.

Os rendimentos médios das plantações de café repousam no Paraná em 34\% dos cafeeiros abaixo de 10 sacas de $60 \mathrm{~kg}$ de café cru descascado por 1000 árvores; em 35\% entre 10 e 16 sacas, e em 31\% acima de 16 sacas $^{352}$. Com isso, o Paraná, com somente $17 \%$ dos pés de café, se encontra bem acima da média brasileira no grupo de produtividade acima de 16 sacas (> $960 \mathrm{~kg} / 1.000$ pés). Isso não é consequência de uma ampla adubação disseminada, mas sim da alta fertilidade natural da terra roxa do Norte Novo.

Figura 13: Rendimentos das plantações de café G. Schlieper/Rolândia

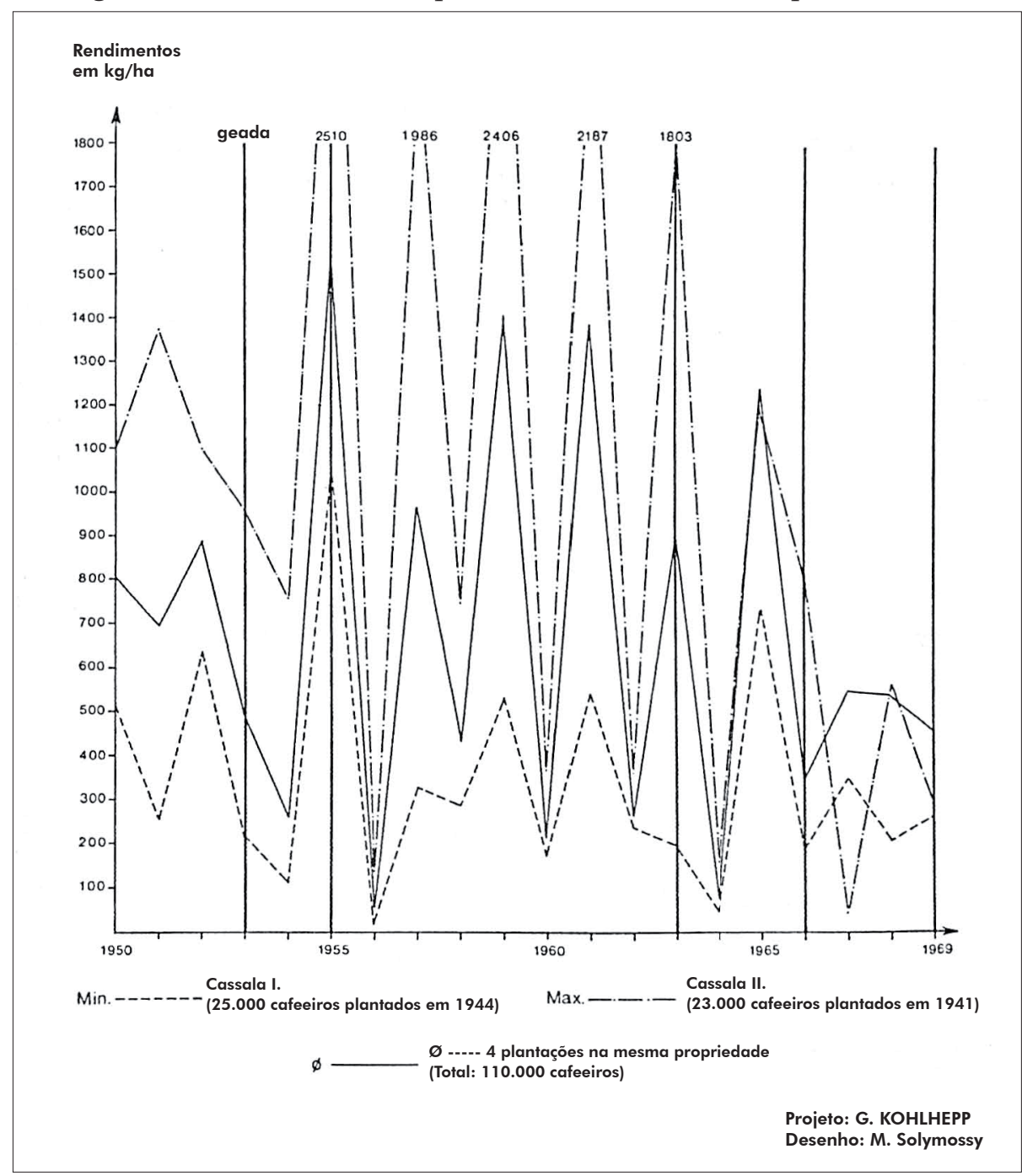

Fonte: Informações pessoais do proprietário.

351 IBC, Anuário Estatístico do Café, 1972.

352 Em São Paulo: 64\% até 10; 25\% entre 10 e 16; e 11\% acima de 16 sacas de 60 kg/1.000 pés de café (IBC/Gerca, Plano de Renovação e revigoramento de cafezais, [s. d.], p. 27). - O rendimento médio correspondeu em 1957 a 390 kg/1.000 pés. 
Os rendimentos máximos das fazendas e dos sítios intensivamente cultivados estão muito acima dos valores citados. A Fazenda Ubatuba no município de Apucarana, uma das maiores plantações do Norte Novo, com uma plantação de café de 453.000 cafeeiros (1970), aponta em um período de 22 anos, incluindo a queda total de produção da colheita de 1956 após a forte geada de 1955, um rendimento de $1960 \mathrm{~kg} / 1.000$ pés em maturidade produtiva. A colheita máxima foi atingida em 1967/68 com $3.780 \mathrm{~kg} / 1.000$ pés, o que, no estoque da época de quase 500.000, resultou numa colheita de 94.400 sacas de $60 \mathrm{~kg}$ de café cru! ${ }^{353}$

No ritmo de produção, segue-se a uma boa colheita um ano com rendimentos mais fracos. Isso fica claro na Figura 13, na qual são analisados, no decorrer de 20 anos, os rendimentos de quatro plantações de café médias em posse do mesmo produtor. ${ }^{354}$ Os empreendimentos diretamente vizinhos entre si no município de Rolândia receberam o mesmo cuidado e adubação. Apesar disso, a diferença entre o empreendimento com os rendimentos mais altos (Cassala II) e com os mais baixos (Cassala I) é extremamente grande (média/1.000 pés: $1.765 \mathrm{~kg}$ e $844 \mathrm{~kg}$ ). ${ }^{355} \mathrm{O}$ motivo dessa diferença de rentabilidade se deve tanto à diferente exposição das plantações, das quais as mais fracas em rendimentos ficam para o sul, bem como também à altitude por volta de $80 \mathrm{~m}$ mais baixa de Cassala $\mathrm{I}$, em parte em um recorte de vale. Geadas de vento e de radiação, bem como correntes de ar frio, geralmente pouco perceptíveis nas áreas protegidas e mais altas, fazem que os rendimentos em Cassala I se reduzam a pouco mais do que a metade, na média de muitos anos.

O mesmo fenômeno pode ser observado em duas plantações localizadas em lados diferentes de um espigão (Mapa 54), que são de mesma propriedade e administração e exploradas de forma semelhante. A Fazenda Balu é exposta para sudoeste, a plantação do Sítio Pindorama para leste/nordeste. Nos ventos gelados incidentes do sul e do sudoeste, os danos devidos à geada em Balu são mais significativos, de forma que o rendimento médio fica somente em $1.260 \mathrm{~kg} / 1.000$ pés, enquanto que em Pindorama fica em $1.638 \mathrm{~kg}^{356}$. Nisso as diferenças ocorrem menos após fortes geadas de radiação (em 1956 e 1970 a produção caiu totalmente em ambas as plantações), mas sim mais após fracas geadas de vento, que têm consequências menores em Pindorama, localizada na posição leste. Na encosta voltada a oeste/sudoeste do sítio deixou-se a vegetação nativa original.

Grandes problemas são causados pela erosão do solo nos pequenos empreendimentos, cuja linha de propriedade vai do espigão ao vale. A plantação de café foi realizada verticalmente em relação ao declive, e em razão da largura comum de somente 150-250 m a construção de diques é pouco eficaz. Isso atinge, sobretudo, as regiões da CMNP, nas quais a pequena distribuição agrária espacial aponta o modelo de distribuição característico para o Norte Novo em torno de Londrina e Maringá, mas também no Norte Novíssimo a leste de Cianorte (Mapas 52 e 53).

As encostas são compostas em até um terço por plantações de café. Nas áreas mais altas sobre as divisoras de águas ('espigões'), os cafeeiros das melhores áreas foram em parte substituídos por novas variedades (Mundo Novo). Em grande parte as culturas paralelas são realizadas em meio às plantações de café. No limite inferior do cultivo de café fica a residência do proprietário, seu pomar, chiqueiro, bem como algumas plantações para subsistência. O solo de vale, fortemente ameaçado por ar frio descendente, é ocupado por pastagens artificiais. O sítio no Mapa 53 obtém $90 \%$ de seus rendimentos a partir do cultivo de café (14.000 cafeeiros, $72 \%$ da área de empreendimento), e o restante, da venda de produtos de culturas paralelas (arroz, milho), bem como de suínos de engorda. A plantação de café alcança o fundo da encosta e sofre prejuízos nas suas partes mais baixas quando há inversão de temperatura, como no ano de 1963.

\section{b) Localização e ordem espacial do cultivo de café no Norte Novo e Norte Novíssimo}

A concentração das localizações do cultivo de café na região com as condições naturais mais favoráveis ocorreu nas novas plantações já no início dos anos 1960 e ainda foi relativamente acentuada durante a fase de erradicação através da redução das reservas em áreas inadequadas.

353 A idade dos cafeeiros correspondia a 5-26 anos, em média por volta de 18 anos (informação pessoal na Fazenda Ubatuba).

354 Aqui se agradece ao Sr. G. Schlieper (Rolândia) por seu cordial apoio na compilação de dados sobre a produtividade das plantações de café.

$355 \mathrm{Na}$ densidade de plantio existente, esses valores correspondem a 1.034 ou $447 \mathrm{~kg} / \mathrm{ha}$. O valor máximo de 2.510/ha no ano de 1955 corresponde a um resultado Recorde de $4.249 \mathrm{~kg} / 1.000$ pés de café.

356 Informações gentilmente cedidas pelo Sr. H. M. Bresslau, Rolândia. 
A distribuição espacial dos pés de café (vide Mapa 50 ${ }^{357}$ mostra que as plantações se estendem principalmente sobre as encostas mais altas e evitam as baixadas em razão do risco de geada em caso de inversão de temperatura (Mapa 52). O adensamento das reservas ocorre entre Mandaguari e Nova Esperança, enquanto que o restante do Norte Novo mostra um modelo de distribuição relativamente equilibrado nas áreas altas apropriadas. Ao sul do Ivaí ainda há plantações extensivas de café nos municípios de Terra Boa, Jussara, São Tomé e Japurá, localizados na região de 'terra roxa', assim como no esporão de São João do Ivai - Jardim Alegre - Ivaiporã, na maior região meridional de cultivo. A oeste se destaca claramente das regiões vizinhas a atual área pioneira de Umuarama - Xambré Pérola.

A produção de café, a exemplo do ano do café de 1968/69 (safra 1968, ano normal), mostra um forte sobrepeso do Norte Novo (região de Londrina e Maringá). No ápice se encontram os municípios de Maringá, Rolândia e Londrina com mais de 600.000 sacas de café cru (de $60 \mathrm{~kg}$ ), seguidos por uma série de municípios vizinhos na área do espigão entre Ivaí e Pirapó, bem como Paranapanema e Ivaí (Mapa 50). Na interpretação das cifras de produção deve-se, entretanto, considerar que se tratam de valores do registro de colheita das agências $I B C$, ou seja, de uma colheita registrada em um município, que também pode se referir a municípios vizinhos.

O fato de 39\% dos pés de café do Norte do Paraná se localizarem em terrenos arenosos pouco férteis explica a pequena produção do Norte Novíssimo, que se aproxima muito pouco do volume das plantações de café do Norte Novo (Tabela 45). Após 12-15 anos de uso, os rendimentos já retrocederam fortemente nas regiões pioneiras do Noroeste e Oeste, apesar de os pés de café estarem na sua melhor fase de produção nessa idade.

Após a geada de 1969, iniciou-se um programa de renovação sucessiva das plantações de café do Brasil, que depois da ocorrência do fungo da ferrugem (Hemileia vastatrix) se concentra nas regiões de cultivo ao norte (ver Cap. VIII, 5), sobretudo nos estados de São Paulo e Paraná, bem como no sul de Minas Gerais.

Apesar de na área observada somente $11 \%$ do efetivo de pés de café serem mais velhos do que 20 $\operatorname{anos}^{358}$ (entre 4 e 20 anos: $84 \%$; ate 5 anos: 5\%), esses exemplares vêm sendo cada vez mais substituídos por novas plantações. Nos primeiros 7 meses do ano de 1970 foram plantados por volta de 4 milhões de pés de café (vide Mapa 51), um número muito aquém dos planos do IBC, mas que se justifica tendo em conta a postura hesitante dos plantadores de café após o choque da já prevista queda quase total da safra em 1970. 62\% das plantações novas foram realizadas por contratos com o IBC, que asseguram um financiamento dos trabalhos de cultivo através do Banco do Brasil.

O motivo das novas plantações dentro das regiões individuais é claramente diversificado ${ }^{359}$ (em \%):

Expectativa de alta rentabilidade

Norte Novo

Norte Novíssimo ao norte do Ivaí

Norte Novíssimo ao sul do Ivaí

\section{7}

29

46
Venda garantida

11

41

29 melhor
possibilidade

52

1

13
Tradição dos

plantadores de café

20

29

12

Nas zonas pioneiras do Norte Novíssimo, sobretudo ao sul do Ivaí, o espírito especulativo ocupa ainda um amplo espaço. A venda garantida da produção foi decisiva ao norte do Ivaí, enquanto que no Norte Novo $52 \%$ dos plantadores entendem a nova plantação de café como melhor possibilidade de uso da terra (sobretudo nos pequenos e médios empreendimentos).

357 Sobre as fontes da apresentação, vide índice de mapas, Mapa 50.

358 Em São Paulo, 31\% dos cafeeiros têm mais de 20 anos. (Dados do IBC e da GERCA).

359 Avaliação de pesquisas de opinião do IBC em 175 celebrações de contrato em 1970. 
O pressuposto para a celebração dos contratos de financiamento é a inspeção do terreno previsto para a plantação pelos agrônomos do IBC. Nisso são considerados como critérios a qualidade do solo, altitude, condição da terra (danos devido à erosão) e a exposição da encosta. O plantador é obrigado a utilizar sementes testadas, a plantar o café em curvas de nível, a tomar medidas preventivas contra a erosão do solo e realizar a adubação. Para incentivar a intensificação do trabalho, são autorizados primeiramente até 20.000 cafeeiros para as plantações. Esse limite foi aumentado para 40.000 a partir de setembro de 1970.

A avaliação dos contratos de plantação celebrados de janeiro até julho de 1970 com o IBC (Figura 14) mostra uma dispersão das altitudes de 400 a $890 \mathrm{~m}$. As ordens de grandeza oscilam entre 2.000 e 20.000 pés, com uma concentração no limite superior. De acordo com as condições de altitude, as novas plantações se localizam acima de 650 m exclusivamente nas regiões de Londrina (parte central), Maringá, bem como em menor monta em Campo Mourão (posição do espigão). As plantações autorizadas nas altitudes abaixo de $500 \mathrm{~m}$ estão localizadas nas partes mais ao norte do Estado, menos atingidas pela geada, na região de Paranavaí e no norte da região de Londrina.

Figura 14: Altitude e extensão das novas plantações de café de janeiro a junho de 1970

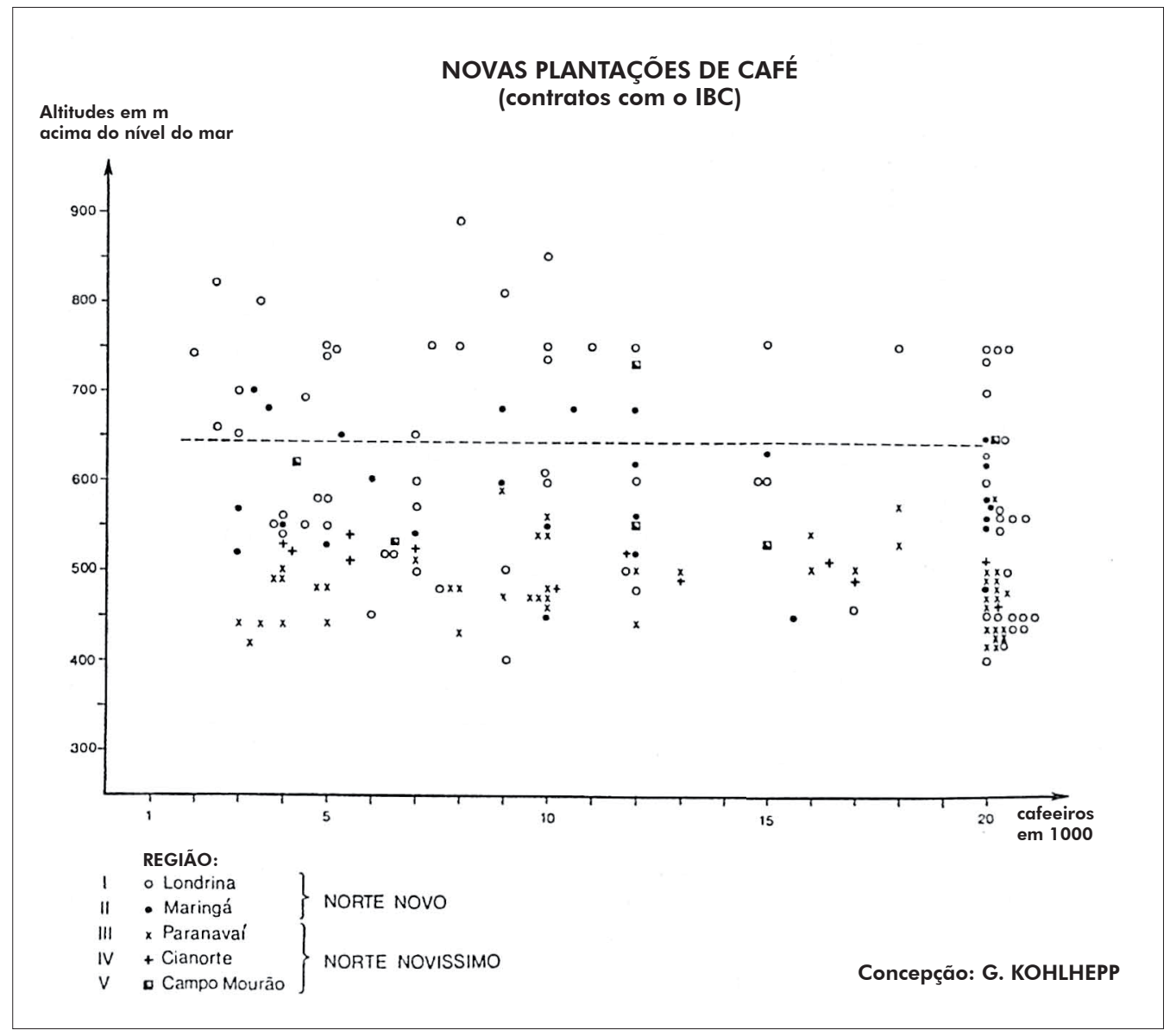

Fonte: Mapa 51.

\section{c) Inovações}

Faz parte das inovações mais significativas no âmbito da economia do café no Norte do Paraná a colocação de canteiros, nos quais se faz uso de sementes selecionadas de café em pequenos recipientes cilíndricos de plástico preenchidos com terra de húmus. Os canteiros são protegidos contra geada de 
vento e radiação solar direta através de uma cobertura colocada por volta de $2 \mathrm{~m}$ acima do solo, através da qual se pode dosar a insolação conforme as plantas vão crescendo. Após 7 meses as plantas são mudadas, entre outubro e junho, para a terra preparada na medida de duas para cada grupo de plantas (Foto 13).

Ao contrário do sistema antigo, em que se colocavam 4-6 sementes (frequentemente até mais) diretamente nas covas de $20-30 \mathrm{~cm}$ de profundidade e se as cobriam com varas de madeira durante 12 a 18 meses, no novo sistema os pés de café jovens começam a produzir cerca de um ano antes. Esse método foi disseminado mais fortemente apenas em São Paulo, mas vinha sendo propagado pelo IBC à época da realização deste estudo e utilizado de forma crescente no Paraná, sobretudo no Norte Novo central, tanto pelas cooperativas de plantadores de café como, também, pelos plantadores individuais ${ }^{360}$.

A escolha de sementes de qualidade e o cuidado intensivo no primeiro estágio de crescimento têm valor especial. Além disso, há a densidade de plantação (até 3,5 × 2,3 m, em parte), que vem diminuindo em relação ao período anterior $(3,8 \times 3,8 \mathrm{~m})$, vide Foto 6 .

Também houve inovações significativas entre as variedades de arábica plantadas. Até meados dos anos 1950, Bourbon predominava nas plantações de café paranaenses a oeste do rio Tibagi. A antiga variedade brasileira Typica (também conhecida como 'Comum' e 'Nacional') foi substituída por Bourbon, que apontou maiores rendimentos. Na primeira metade dos anos 50 surgiu a variedade 'Sumatra', mas cuja importância até hoje retrocede, assim como a da Caturra. Com a última variedade, uma mutação anã de Bourbon, acreditou-se ter encontrado um tipo resistente à geada (autoproteção) em razão do entroncamento do pé e de seus galhos estreitamente dispostos, que facilitavam sobremaneira a colheita. A geada de 1955 mostrou, porém, que 'Caturra' sofrera extremamente com os danos da geada.

Desde essa época apareceu 'Mundo Novo', uma variedade criada pelo Instituto Agronômico de Campinas, um tipo melhorado de 'Sumatra', mais produtivo e resistente à geada do que seu antecessor. Já em 1960, 45\% do novo café plantado era 'Mundo Novo'. Atualmente, 90\% dos plantadores compram essa semente, de forma que com as novas plantações 'Mundo Novo' a fração de Bourbon continua a decrescer ${ }^{361}$.

Assim, acabou o ciclo das transposições do local de cultivo do café em razão da existência de solos florestais mais férteis. Com a fase de consolidação do plantio de café impõe-se então a adubação cada vez mais forte nas principais regiões de produção.

No Norte Novo fixaram-se ao longo do eixo principal de Londrina a Maringá dez firmas de adubos com filiais, mas que realizam nesse âmbito somente a mistura de tipos e não a produção propriamente. Os anos decisivos do desenvolvimento foram 1967/68. Dentro de um ano cresceu a área adubada de cultivo de café no Norte do Paraná em torno de 45\% (GERCA, 1970c, p. 28). A iniciativa das firmas era a princípio voltada aos plantadores de café. Quando, após o bom início, estagnou o interesse após a geada de 1969, ocorreu uma forte inclinação para os demais produtos agrícolas.

Contudo, atualmente o interesse principal se volta novamente para o café. Para a regeneração dos pés e para proteção contra doenças de plantas começou-se com adubação regular. Na região em torno de Londrina-Rolândia, por volta de $70 \%$ dos plantadores de café adubam, porém no máximo $20 \%$ o fazem corretamente $^{362}$. Segundo dados do IBC, em maio de 1970 foi realizada adubagem artificial em $35 \%$ dos cafezais no Norte Novo; no Norte Novíssimo - apesar da baixa produtividade dos solos arenosos - , somente por $10 \%$ dos plantadores.

Os empreendimentos mistos de café e gado não podem utilizar o esterco gerado devido à falta de instalação de estrebaria para o gado. Por outro lado, alguns empreendimentos com criação significativa de aves (para produção de ovos) têm uma base de adubo orgânico extremamente boa. Assim a Fazenda Balu em Rolândia (Mapa 54) possui, além de uma plantação de 152.000 cafeeiros, uma granja com 30.000 aves. As 300 t geradas de esterco aviário/ano resultam em $2 \mathrm{~kg} / \mathrm{cafeeiro/}$ ano.

360 Em 1970, no Norte Novo somente 24\% possuíam canteiros de café, no Norte Novíssimo 15\%.

361 Cf. sobre isso IBC-OEA (1964, p. 59) e Krug e Poerck (1968, p. 286-87), dados do Instituto Brasileiro do Café, Agência Curitiba, e informações gentilmente cedidas pelo Sr. Bresslau, Rolândia.

362 Segundo dados da Cia. Ultrafertil, Londrina, a relação N-P-K deve corresponder, no $1^{\circ}$ ao $4^{\circ}$ ano do plantio de café, a 10 : $9: 10$; a partir do $5^{\circ}$ ano, $7: 2: 9$, a quantidade de adubo de $600 \mathrm{~g}$ por cova é adicionada em 4 partes iguais em setembro, novembro, janeiro e março. As questões de qualidade do solo e adubação correspondente estão sendo atualmente pesquisadas em um projeto da Comissão de Estudo dos Recursos Naturais Renováveis do Paraná (Cerena). 
Empreendimentos grandes e médios bem conduzidos iniciam com uma reorganização sistemática de suas plantações de café. Assim, por exemplo, a Fazenda Balu de 480 ha (Rolândia), hoje com um total de 152.000 cafeeiros (Mapa 54) arrancou, desde 1963, 34.000 cafeeiros com pouco rendimento ou danificados pela geada. Como a plantação de café se estendeu, no início da colonização, de seu limite atual no terço inferior da encosta em direção ao espigão, a erradicação se iniciou com as reservas mais antigas e mais atingidas pela geada na corrente de ar frio, em razão da altitude. O cultivo de trigo paralelo à encosta (em rotação de cultura com a soja) com arrimos contra a lavagem do solo substituiu nesse âmbito o café.

A mais recente erradicação foi, porém, realizada nas encostas mais altas e as plantas Bourbon foram substituídas por 'Mundo Novo'. Segundo pontos de vista mais modernos, a nova plantação é colocada em curvas de nível ( Fotos 6 e 10). As valas para os novos pés de café, transplantados a partir da produção própria de sementes da fazenda, foram feitas mecanicamente com uma escavadeira ${ }^{363}$ (Foto 13). A Fazenda Balu faz parte dos poucos empreendimentos que deixaram reservas florestais suficientes e que com $25 \%$ da área empreendida (café: $41 \%$ ) se situa muito além da média de 6,5\% (1968) indicada pelo IBC para o Norte Novo ${ }^{364}$.

O empreendimento que arrecada anualmente em média por volta de $70 \%$ de seus rendimentos com o cultivo de café pode apoiar-se, em caso de quebra da safra por danos de geada (por exemplo, em 1970), na venda de rami bem como na produção de ovos, mantendo por volta de 30.000 aves $^{365}$.

No total, a área central de cultivo de café do Norte Novo do Paraná (Mapa 35) mostra uma diversificação essencial do uso da terra em comparação com a monocultura na época do boom do café em meados dos anos 1950. Apesar disso, o cultivo de café continua a manter a hegemonia nessa região.

Tendo como exemplo o mapeamento do uso da terra no município de Marialva (Mapa 55) a leste de Maringá, torna-se evidente a clara tendência de concentração das plantações de café nos locais favoráveis em razão das condições naturais. Ao sul do espigão principal onde se localiza Marialva $(640 \mathrm{~m})$ junto à rodovia asfaltada e da estrada de ferro, estendem-se as extensas encostas em forma de platô entre os pequenos rios ${ }^{366}$ profundamente encravados no vale e que correm para o Ivaí, nas quais predomina o cultivo do café. Grande parte das antigas reservas mostra indícios de degradação por influências dos ventos frios do Sul. Os pequenos vales e, sobretudo, as áreas mais profundas no sul mediano do município são tomados por pastagens e produtos agrícolas anuais bem como por pequenas reservas de mata remanescente. Foi realizada erradicação exclusivamente ao sul do espigão, enquanto que para o norte, na posição de sotavento, as recentes plantações de café extensas ocupam o amplo espigão - que suavemente se inclina para o Rio Pirapó (Mapa 55).

77\% dos 2595 empreendimentos agrícolas (Ø 15,1 ha) do município de Marialva realizam cultivo de café (10,5 milhões de pés), o que corresponde a $72 \%$ dos lucros.

As plantações de café na melhor idade produtiva ocupam $26 \%$ da área do município, as mais antigas e menos produtivas, $18 \%{ }^{367}$ Os pequenos empreendimentos, fracos em capital, em parte ainda fragmentados por divisão real (área média dos empreendimentos com cultivo de café: 8,2 ha!) evidenciam a problemática desse tamanho de empreendimento: somente $2 \%$ dos empreendimentos, apesar de declives em parte acentuados, implantaram arrimos contra a lavagem do solo. Somente $3 \%$ aplicam adubo artificial, e 5\% aplicam adubo orgânico ${ }^{368}$.

No comércio do café fica evidente a dependência que os pequenos empreendimentos têm dos maquinistas locais e regionais (24 no município), que assumem uma posição de comerciante intermediário/atravessador. Estes realizam o beneficiamento dos grãos de café, secos nos locais de secagem (terreiros) dos empreendimentos, até chegar ao produto final, o café cru (limpeza,

363 Os trabalhos ainda estavam sendo realizados durante o mapeamento do Autor, em meados de setembro de 1970.

364 Uso da terra dos empreendimentos com cultivo de café no Paraná: café, 40,4\%; 'outros produtos', 14,9\%; pastos, 30,1\%; floresta, 8,1\%; capoeira (floresta secundária), 1,3\%; outro uso, 5,2\% (segundo dados do IBC para 1968).

365 Informações pessoais da Fazenda Balu. Agradecimentos especiais do autor ao Sr. H.M. Bresslau por seu apoio na aquisição do material e disposição para numerosas discussões.

366 O ponto mais baixo do município de Marialva fica no Ribeirão Marialva, cerca de $290 \mathrm{~m}$ acima do nível do mar.

367 Demais usos da terra (em \% da área do município): 1\% plantação nova de café, 2\% erradicação, 23\% pastagens, 22\% produtos agrícolas anuais, 7\% mata, 1\% outros (áreas construídas, estradas etc.) (cálculo de área segundo GERCA, 1969a.).

368 Dados da Acarpa para 1968. 
descasque, seleção, classificação etc. ${ }^{369}$. Apesar de haver Cooperativas do Café nos municípios vizinhos Maringá e Mandaguari, somente 0,7\% da colheita de Marialva é comercializada através de cooperativas.

\section{d) Cooperativismo e comercialização}

Ao contrário de São Paulo e Minas Gerais, onde todas as grandes plantações de café possuem instalações próprias de beneficiamento e o pequeno empreendimento também tem uma possibilidade de se servir das máquinas descascadoras de café do vizinho, no Paraná essas instalações de beneficiamento estão em posse dos maquinistas, sediados na sede do município e nos postos distritais.

Das 617 instalações de beneficiamento da região investigada, $69 \%$ se situam no Norte Novo, sobretudo na região de Londrina. Desses empreendimentos, $79 \%$ têm sua sede nos municípios, $9 \%$ nos postos distritais e 12\% nas fazendas. Instalações próprias existem, sobretudo, nos municípios de Florestópolis, Bela Vista do Paraíso, Astorga, Alvorada do Sul e Rolândia. Das 194 instalações de beneficiamento do Norte Novíssimo (concentração: região de Paranavaí), 91\% se localizam na sede do município, 6\% nos distritos e somente $3 \%$ nas fazendas ${ }^{370}$.

Em geral, o cooperativismo se desenvolveu de forma muito hesitante no cultivo de café. Os motivos se devem, sobretudo, à postura especulativa dos plantadores no frontier, que não aceitam qualquer 'estreitamento' através de estatutos cooperativistas. Em vez disso, o plantador de café vende sua safra de café de forma tradicional ao maquinista, que paga a colheita ao produtor através de créditos aos bancos locais ${ }^{371}$ e muitas vezes age até mesmo sem capital próprio. O café cru é vendido pelos maquinistas a grandes empresas exportadoras brasileiras e internacionais ou ao IBC.

Essa forma de comercialização mantém-se tradicional no Paraná, apesar de parecer que a grande estrutura das plantações de café tende a uma união cooperativista dos pequenos cafeicultores.

Dos empreendimentos, tem-se a seguinte porcentagem ${ }^{372}$ :

$\begin{array}{lrll}39 \% \text { menos que } & 5 & \text { mil pés de café } & =8 \% \text { da reserva de pés de café } \\ 29 \% \text { entre } & 5-10 & \text { mil pés de café } & =15 \% \text { da reserva de pés de café } \\ 18 \% \text { entre } & 10-20 & \text { mil pés de café } & =19 \% \text { da reserva de pés de café } \\ 10 \% \text { entre } & 20-50 & \text { mil pés de café } & =21 \% \text { da reserva de pés de café } \\ 4 \% \text { mais que } & 50 & \text { mil pés de café } & =37 \% \text { da reserva de pés de café }\end{array}$

A mentalidade de frontier dos cafeicultores pode ser percebida até hoje pela divisão espacial das sedes das cooperativas (Mapa 56). Das 17 cooperativas existentes em 1970 na região de estudo, 12 têm sua sede no Norte Novo, quatro no Norte Novíssimo de Paranavaí, e somente uma ao sul do Ivaí (Cidade Gaúcha). A organização da 'Cotia' tem diversas filiais paralelamente no Norte do Paraná, que comercializam café, entre outros produtos. Com exceção da "Cotia" e três cooperativas de cafeicultores (Ibiporã em 1947, Londrina em 1956, Apucarana em 1959), todas as outras cooperativas foram fundadas nos anos de 1961 a 1964, em sua maioria em 1962/63. As cooperativas em Iguaraçu e São João do Caiuá encerraram suas atividades.

369 V. p. 88.

370 Avaliação própria dos dados sobre beneficiamento do café cf. IBGE, Cadastro Industrial 1965, v. 8, Estado do Paraná.

371 Aqui se testa, com base em um modelo, a renda do café em casca; em geral, três sacas de $40 \mathrm{~kg}$ de café com casca resultam em uma saca com $60 \mathrm{~kg}$ de café cru descascado pronto para o comércio. Além disso, é avaliada a qualidade. O preço de compra é composto por ambos.

372 Segundo uma análise de amostra do IBC para 1968 (IBC, 1970a, p. 5). 
O total de 4.437 membros (somente 7,5\% de todos os empreendimentos de café) das cooperativas têm 68,5 milhões de pés de café, ou seja, quase 10\% de todas as reservas. Os proprietários de tamanhos diferentes de empreendimentos estão representados de forma relativamente equilibrada entre os membros. Segundo avaliação dos dados de 920 membros de cooperativas, ${ }^{373} 35 \%$ dos pequenos empreendedores possuem menos de 15 mil pés de café, 42\% de empreendimentos médios detém 15-50 mil, e $23 \%$ mais de 50 mil pés de café.

As áreas de inserção das cooperativas (vide Mapa 56) são bem diversificadas. Mandaguari e Maringá têm um caráter suprarregional. Também Paranavaí e Nova Londrina, tem uma área de inserção maior, com membros no município de Naviraí (Mato Grosso do Sul), mas que não produzem café.

As cooperativas oferecem a seus membros uma série de vantagens significativas: melhores possibilidades de preparação do café com modernas máquinas descascadeiras e selecionadoras com grande rendimento diário em alta qualidade do produto final; ${ }^{374}$ a possibilidade de controlar a venda, desviando-se dos maquinistas, conforme as realidades do mercado; uma grande participação na margem de lucro para os produtores; e melhores possibilidades de armazenamento. ${ }^{375}$ Elas realizam a consultoria agroeconômica para os membros, e em geral possuem boas vinculações bancárias para aquisição de crédito. Como a cooperativa vende o café cru de seus membros um a um, segundo classes de qualidade, não se impede a própria iniciativa dos plantadores para a produção de qualidade. A comercialização cooperativista impede sobretudo os lucros especulativos dos comerciantes. No âmbito das mudanças estruturais agrárias, as cooperativas, ao lado de sua especialização no café, também se voltaram, em parte, à preparação e comercialização de algodão, arroz e milho.

Às cooperativas se conferiu uma função importante nos trabalhos preparatórios do IBC para fixação do cinturão do café e eventual determinação de cotas de produção.

Apesar de todos os aspectos positivos das cooperativas dos cafeicultores, somente $2,5 \%$ da colheita de 1968/69 foram comercializados através das cooperativas, 68,3\% porém através dos maquinistas. ${ }^{376}$ Disso, dois terços foram através de maquinistas regionais independentes e um sexto através de firmas estrangeiras, cujas filiais atuam como compradores de café na região de produção. Somente $4 \%$ da colheita foram beneficiados por pequenos maquinistas, e por volta de $5 \%$, diretamente nas fazendas. $\mathrm{Na}$ exportação, a proporção entre firmas regionais e estrangeiras é 60:40.

Para apoiar o preço do café, o Instituto Brasileiro do Café compra grandes quantidades de café dos maquinistas, conforme a situação do mercado. Para evitar a longa estocagem nas cidades portuárias quentes e úmidas, o IBC instalou uma rede de depósitos na região de cultivo. As sedes se localizam - com poucas exceções - bem junto às estradas principais e à linha férrea (Figura 15). A capacidade total dos 41 depósitos, dos quais 25 se localizam no Norte Novo, é de 31 milhões de sacas no Norte do Paraná. Ao final de 1969, os depósitos estavam completos com 15,2 milhões de sacas num total de $57 \% .377$ Os maiores depósitos do IBC possuem uma capacidade de estoque de mais de 1 milhão de sacas (Londrina, Rolândia, Arapongas, Apucarana, Maringá, Paissandu) ${ }^{378}$

373 Entrevistas detalhadas foram realizadas pelo autor em Londrina, Mandaguari, Maringá, Paranavaí e Porecatu. Dados complementares sobre as demais cooperativas provém de documentos do IBC em Maringá.

374 A capacidade/dia fica entre 600 e 2.000 sacas.

375 No total para 1,7 milhões de sacas a $60 \mathrm{~kg}$.

376 Dados de Gerca/IBC através de gentil intermediação do Sr. Dr. Meirelles, Curitiba.

377 Folha de Londrina, 11/12/1969. - Em razão da pouca safra brasileira de 1970 (quase perda total da safra no Paraná), o IBC cobriu as obrigações de exportação de café do Brasil a partir desses estoques.

378 Além do IBC, cooperativas e maquinistas, também a linha férrea possui uma rede própria de 34 depósitos, entretanto com menor capacidade de estocagem: 0,6 milhões de sacas. 


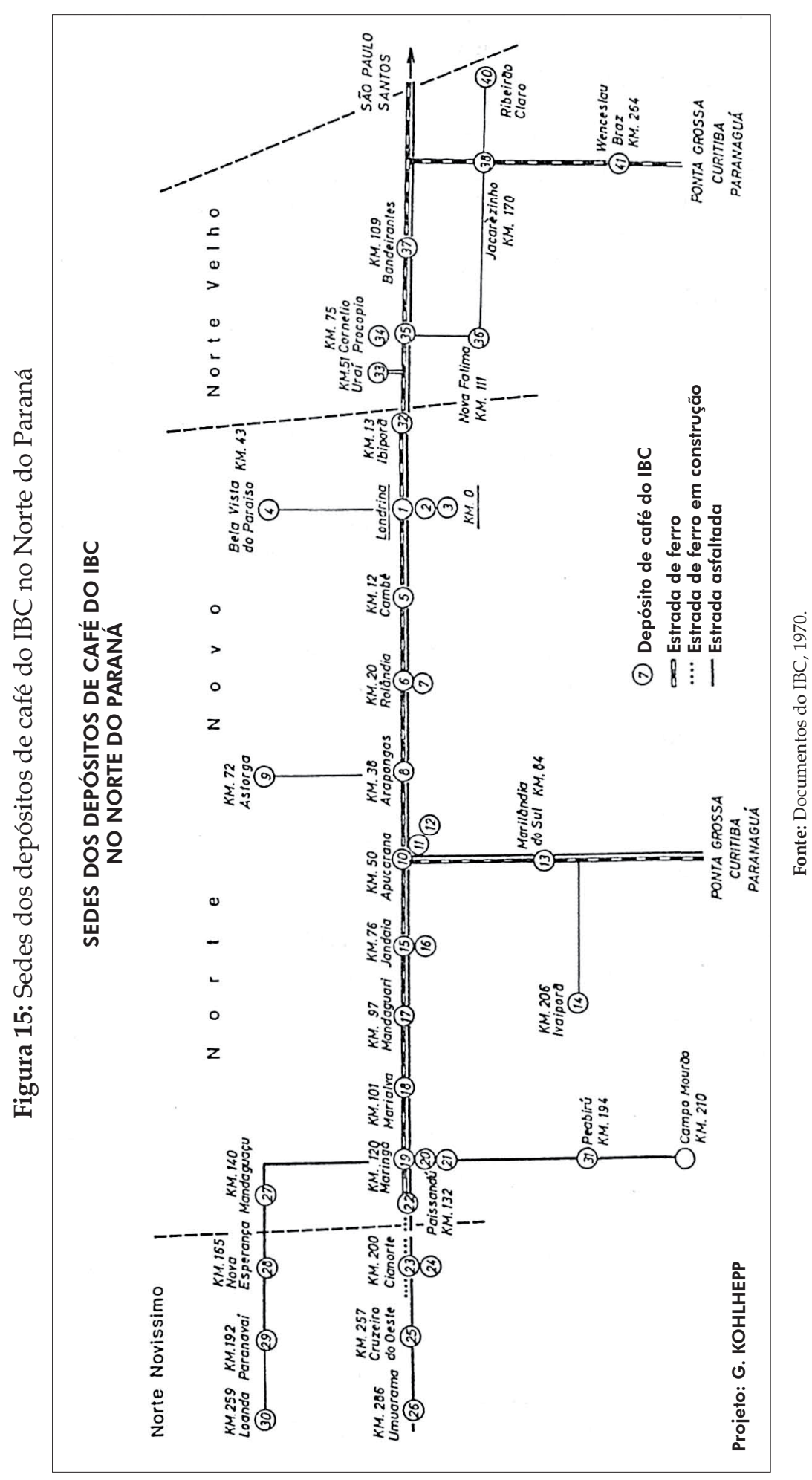




\section{e) Estrutura de transportes da região cafeicultora}

A urbanização do Norte do Paraná provinda de São Paulo fez que a região cafeicultora do Paraná se tornasse um 'guindaste' das zonas pioneiras paulistanas, em razão das conexões viárias e da origem populacional, em direta dependência econômica de São Paulo. Uma conexão por rodovia asfaltada de Londrina a São Paulo-Santos existia muito antes de haver uma estrada transitável o ano todo entre o Norte e o Sul do Paraná. A linha férrea da antiga estação final de Maringá à capital Curitiba e ao porto de Paranaguá leva a leste até a divisa estatal com São Paulo através de Ourinhos - o ponto de conexão ao trecho da Sorocabana -, e somente dali para o sul em direção a Ponta Grossa - Curitiba. Assim, ocorreu que a conexão férrea ao porto paulistano de Santos não era muito mais longa que a conexão até Paranaguá (Mapa 58).

Depois que a Rodovia do Café - uma rodovia asfaltada de Apucarana até Ponta Grossa e Curitiba - possibilitou, desde 1965, o transporte de café diretamente a Paranaguá, foi recentemente terminada a construção da central da linha férrea Central do Paraná, que reduz o trecho Apucarana-Ponta Grossa para $330 \mathrm{~km}$ em conexão direta. Antes eram $624 \mathrm{~km}$, através de Ourinhos. Além de significativo ganho de tempo, isso também diminui os custos de transporte ${ }^{379}$.

A situação dos transportes do Norte do Paraná modificou-se essencialmente nos últimos anos. ${ }^{380}$ Mas isso vale quase que exclusivamente para a construção de estradas, pois a linha férrea para o Oeste foi continuada somente de forma muito hesitante e, após a conclusão da ponte sobre o Ivaí, chegou primeiro a Cianorte, sem ter sido conectada ao trânsito de carreira, até a conclusão do presente estudo. Por outro lado, a malha viária asfaltada foi ampliada (Mapa 57) e Maringá se tornou o ponto de entroncamento dos trechos a Paranavaí, Campo Mourão e da rodovia principal a Umuarama, terminada em 1971. Em Rolândia bifurca a planejada conexão asfaltada com São Paulo, mas que termina em Porecatu. A rodovia principal de Londrina a Maringá é fortemente utilizada, e em 1969 acusou nos trechos entre Londrina e Cambé um fluxo diário de 7.270 veículos, e de Maringá em direção a Marialva até mesmo 8.475 veículos por dia. ${ }^{381}$

Para o sul continua a existir somente uma via transversal asfaltada (Apucarana-Ponta Grossa) entre os eixos principais leste-oeste São Paulo - Londrina - Umuarama e Paranaguá - Curitiba - Guarapuava Foz do Iguaçu, que assinalam o processo de urbanização no Norte ou no Sul. ${ }^{382}$ Fora das vias asfaltadas existem, nas estradas naturais do Norte do Paraná, condições viárias muito precárias em caso de chuva. Na região arenosa do Noroeste, as estradas principais sem macadame de Paranavaí a Nova Londrina e Loanda estão frequentemente intransitáveis por conta da voçoroca. Mas também na região de terra roxa, após fortes precipitações, as estradas vicinais não são transitáveis devido ao risco de deslizamento.

Os pontos finais das estradas asfaltadas são os locais de confluência para a continuação do transporte de produtos agrícolas. Durante grandes colheitas de café todos os veículos disponíveis são utilizados para o transporte, seja para os maquinistas, para os depósitos do IBC ou diretamente para os portos de exportação.

No transporte ferroviário, Maringá, como ponto final efetivo do trecho principal, continua a ser o local mais importante de coleta e transbordo. Segundo o valor das mercadorias expedidas, Maringá ocupa o primeiro lugar em todo Paraná, antes mesmo de Paranaguá383.

\section{f) Exportação de café e diferenciação de qualidade}

Até meados dos anos 1920, as colheitas de café do Norte Velho tinham sido transportadas exclusivamente através de Santos. Desde 1924, pequenas quantias também foram transportadas a partir do Norte Velho em Paranaguá. A ascensão de Paranaguá ocorreu paralelamente ao desenvolvimento do cultivo de café no Norte Novo e Norte Novíssimo. Ainda no início dos anos 1950 existia, porém, um transporte oculto do café paranaense por estrada até as estações da via férrea Sorocabana, para de lá ser

379 Para o desenvolvimento da condição de transporte, v. Brum (1964) e Revista de Desenvolvimento n. 3, 1967, p. 13ss. (Central do Paraná) = Fayet, 1967.

380 Mapa 17 (situação dos pioneiros em 1948) e Mapa 57 (desenvolvimento da malha viária em 1971).

381 Informação do Departamento de Estradas e Rodagem (DER) em Curitiba, para 1969.

382 No Mapa 57 é visível a rodovia de longa distância Paranaguá-Assunção/Paraguai passando por Cascavel no sul.

383 Segundo informação da Rede de Viação Paraná - Santa Catarina (RVPSC - Setor de Estatística) em Curitiba, para o ano de 1969. 
enviado para Santos ou Rio como café paulista, que alcançava um preço melhor. Sobretudo em Santos as transações eram mais fáceis em razão da tradição do café desse porto e das instalações de carregamento substancialmente melhores (GUIMARÃES, 1953, p. 57).

A ampliação do Porto de Paranaguá e as conexões de transporte com as regiões de produção de café do estado acarretaram na integração do Norte com o sistema de transporte paranaense. Com isso, em grande parte, a exportação de café saiu do âmbito de influência paulistana (Mapa 58).

A exportação de café do Norte do Paraná se deu, em 1969, 87\% por Paranaguá. O transporte ao porto foi feito em $79 \%$ por caminhão e somente $21 \%$ por trem. O café paranaense exportado por Santos (aproximadamente um milhão de sacas) foi transportado na mesma proporção por estrada e por via férrea. ${ }^{384}$

Desde o surgimento da conexão por estrada asfaltada da região de cultivo ao porto de exportação (1965), diminuiu a parcela do transporte mal organizado e demorado por ferrovia. A nova via férrea que cruza o Paraná Central irá assumir a parte do carregamento da via férrea do antigo trecho no leste do estado que, com isso, irá perder totalmente sua importância. Face aos problemas gerais de transporte das ferrovias brasileiras não se pode esperar que, na exportação de café, o transporte por ferrovia possa superar o fornecimento direto por caminhão. Em 1969, Paranaguá tinha quase superado Santos, que até então era o porto mais importante de exportação de café do planeta. Entrementes Paranaguá foi novamente remetido ao segundo lugar por Santos. ${ }^{385} \mathrm{O}$ porto paranaense não é especializado somente em exportação de café, mas possui também significativa exportação de milho, que na quantidade supera o café. Entretanto, no valor de transbordo o café está muito além na liderança, com $83 \%$, antes do milho $(8 \%)$ e madeira $(6 \%)$.

Na diferenciação entre tipos e sabor do café exportado através de Santos e Paranaguá e no destino de exportação refletem-se as diferenças de qualidade do café produzido nas diversas regiões brasileiras de cultivo, bem como dos costumes internacionais de consumo (vide Mapa 58). O café é classificado em razão do número de 'defeitos' ${ }^{386}$ por $300 \mathrm{~g}$ de modelo cru em 8 tipos, segundo uma graduação de qualidade 1-8 (com valores intermediários). Tipo 1 corresponde à pureza excelente do produto. Enquanto em Santos os tipos 2, 2/3, bem como 3 e $3 / 4$ predominam, em Paranaguá prevalece o tipo 6 (53\%). O motivo dessa diferença na pureza do café cru repousa, por um lado, na pior preparação feita no Paraná; por outro, os diversos processos de trabalho no Paraná são realizados forçosamente de maneira superficial, pois a colheita se inicia somente em junho (um mês mais tarde do que São Paulo) e até as chuvas de setembro todo o processo deve estar concluído, inclusive secagem e preparação. Isso se expressa na diminuição da qualidade de tipos. Só muito lentamente os cafeicultores estão se adaptando da fase pioneira da produção em quantidade (que São Paulo já superou) para a produção com qualidade. A ampliação do setor cooperativo e a consultoria por agrônomos do IBC poderiam oferecer ajuda essencial nesse sentido.

Além do tamanho dos grãos, da aparência (cor e condição superficial) e do grau de pureza (tipo), tem importância especial o sabor (qualidade de xícara; 'bebida'). Ao contrário dos milds, ou seja, todos os arabicas não brasileiros, as espécies de café do Brasil pertencem ao sabor 'forte'. Nisso tem papel decisivo a técnica da colheita, que no Brasil é realizada em grande parte através da derriçagem dos grãos de café sobre o solo, bem como a preparação. No Brasil aplica-se o processo 'seco' em razão das enormes quantidades de colheita. Como grupos principais se distinguem 'mole', 'duro', 'riada' e 'rio'387, em que os dois últimos possuem um sabor mais forte. Enquanto em Santos 31\% do café exportado tinham um sabor 'suave' (procedência de regiões de cultivo mais secas: Mogiana, Ribeirão Preto, Franca), em Paranaguá $93 \%$ pertencem ao grupo riada.

Esse sabor, por motivos de preço, é utilizado, sobretudo, na fabricação do café solúvel nos Estados Unidos, de forma que quase um terço do café paranaense é exportado aos Estados Unidos por Paranaguá. A República Federal da Alemanha importa somente 1,4\% do café riada. De Santos partem 35\% das

384 Segundo dados de RVPSC, DER e das administrações portuárias em Paranaguá e Santos (em parte, estimativas).

385 Exportação de café em 1972: Santos: 9,055 milhões de sacas de 60 kg; Paranaguá: 7,071 milhões de sacas de 60 kg (IBC, Anuário Estatístico do Café 1972).

386 Grãos pretos, partidos, ocos ou verdes, casca com calosidade, lascas de madeira ou pequenas pedras etc. Esses defeitos e impurezas são calculados em um complexo sistema sobre 'defeitos básicos' de um 'grão de café', que corresponde, por exemplo, a 3 cascas com calosidade ou 5 grãos verdes ou partidos. Tipo $1=0$ defeito; tipo 8 até 360 defeitos.

387 Esse sabor vem, sobretudo, das regiões de cultivo muito úmidas e de locais mais baixos nos estados do Rio de Janeiro e Espírito Santo. 
exportações qualitativamente melhores para os países da CEE (Comunidade Econômica Europeia) 388 (entre esses $9 \%$ à RFA) e somente $16 \%$ aos Estados Unidos.

\section{g) Panorama geral}

Devido à intenção do Brasil de aumentar a própria produção de café solúvel, desenvolveu-se uma acirrada controvérsia com os Estados Unidos, que tentam manter o barato produto brasileiro longe de seu mercado. Sob a pressão americana, o Brasil impôs um imposto de 13\% sobre exportações de café solúvel, que à indústria americana parece muito baixo. Como o Brasil é fortemente dependente dos Estados Unidos como grande importador de café cru, a indústria brasileira de café em pó não pode trabalhar com total eficiência. A importância que esse ramo industrial poderia assumir é revelada pela Cia. Cacique em Londrina, que em 1970, com uma produção diária de 30t de café solúvel, forneceu sozinha quase $1 \%$ do valor brasileiro global de exportação. ${ }^{389}$

A regulamentação da prorrogação do acordo internacional sobre o café depende da questão do café solúvel. A isso se agregam discrepâncias sobre o valor das cotas de exportação, bem como sobre ajustes especiais que a CEE quer garantir às ex-colônias francesas da África ${ }^{390}$.

Também após o fim do boom do cultivo de café nas novas regiões, a situação do cultivo brasileiro de café, com fortes oscilações de produção dos últimos anos devido a geadas no Paraná e à seca em São Paulo, prejudicou fortemente e perturbou o mercado internacional de café. A grande dificuldade de se fazer uma previsão sobre as futuras colheitas brasileiras (ROURKE, 1970) ainda aumenta com a surpresa da ocorrência do fungo da ferrugem no café. As reservas brasileiras de café reduziram fortemente nos últimos cinco anos em razão da diminuição da produção para cumprir as obrigações do ICA, bem como devido a más colheitas. Desde 1966, a produção de café do Brasil indica um déficit anual que pôde ser coberto por meio das reservas estocadas (vide Figura 6). Outra geada no Paraná nos anos seguintes iria consumir o capital de café do Brasil e, com isso, levar a desenvolvimentos internacionais descontrolados do mercado (ROURK, 1971, p. 4ss.).

O desenvolvimento da economia cafeeira no Paraná irá depender de a parcela do mercado no Brasil, ou seja, as 'arábicas' não lavadas, manter os 37,5\% na exportação total do café mundial, como o ICA previu. Outro fator é se as 'robustas', como espécies baratas, podem continuar elevando sua fração de mercado, sobretudo em vista da expansão do mercado para café solúvel.

\section{CONSEQUÊNCIAS DO DESMATAMENTO EXCESSIVO NO CURSO DA COLONIZAÇÃO CAFEICULTORA PARANAENSE}

No curso da colonização agrária, a vegetação florestal tropical do Norte do Paraná, bem como as florestas úmidas subtropicais e as florestas de Araucária da região marginal do sul foram, em grande parte, destruídas. Responsáveis por esse desenvolvimento foram a instalação de cultivos permanentes até o início dos anos 1960 e a partir deste momento em crescente medida a constituição de pastagens de arroteamento. A instituição de grandes reservas florestais governamentais sob o interventor Manuel Ribas sofreu retrocesso através de seus sucessores, de maneira que hoje apenas restos muito reduzidos de floresta estão ainda presentes.

Pressupondo um ritmo de desmatamento constante desde os cálculos de Maack para meados dos anos 1960 (MAACK, 1963, p. 25ss.; MAACK, 1968, p. 196-200), restam hoje apenas 12 a 13\% de floresta na área em estudo, ou seja, desde o início da colonização, há pouco mais de 40 anos, quase $50.000 \mathrm{~km}^{2}$ de floresta foram destruídos, em geral através de queimadas.

A tentativa de mapear os remanescentes de floresta ainda disponíveis (Mapa 59) ${ }^{391}$ mostra que a vegetação florestal originária no Norte Novo desapareceu quase por completo. Apenas na região

388 Designação para o estágio anterior da União Europeia (N. E.).

389 Dados segundo a empresa correspondente em Londrina.

390 Ver sobre isso Frederick (1970, p. 256ss.) e The Standard Bank Review (Londres), 1970, p. 2-9.

391 Fontes: vd. índice de mapas, bem como fotos aéreas mais recentes e dados da Escola Florestal em Curitiba. 
de afluência do Ivaí (Norte Novíssimo) ainda restam áreas contínuas de floresta úmida, em que foi surpreendentemente descoberta, ainda nos anos 1950, uma pequena tribo de índios Xetá (MAACK, 1962). Notícias recentes afirmam que a destruição desses remanescentes de floresta avançou fortemente nos dois últimos anos.

O desflorestamento radical no Norte do Paraná teve como consequência uma crescente instabilidade de fatores climáticos, bem como erosões extremamente fortes, cujas consequências são imprevisíveis.

A acentuada fronteira climática entre o clima de savana de inverno seco a oeste de São Paulo e o clima sempre úmido da região de floresta tropical ao norte do Paraná (que antigamente coincidia com o vale do Paranapanema) já não pode mais ser claramente reconhecida. Revezam-se no Norte do Paraná tempos secos acentuados no inverno, que podem se estender, em parte, de maio até setembro, com fortes chuvas de inverno, que senão só são conhecidas nas regiões mais ao sul do Brasil.

Não apenas a distribuição sazonal de precipitação, mas também os volumes anuais de precipitação apresentam uma instabilidade significativa. Tempo de plantio e processos de amadurecimento do plantio de diversas culturas atrasam-se por meio disso e causam grandes perdas nas culturas, provocando crescente insegurança entre os plantadores. As oscilações nos rendimentos das colheitas no cultivo de produtos agrícolas anuais e o problema de se encontrar um segundo produto economicamente favorável além do café também devem ser levados em conta neste contexto.

O coeficiente de variação na precipitação, que ficava entre 1,4 e 1,6 na paisagem natural da região tropical do Norte do Paraná, duplicou em poucas décadas. Valores extremados aparecem cada vez com mais frequência (MAACK, 1960, p. 3.).

A quantidade de infiltrações de ar frio aumentou. De 1962 a 1969 ocorreram quatro geadas. Um avanço dessa concentração de danos causados por geada, que até 1974 felizmente ainda não ocorreu, traria problemas existenciais à economia cafeeira do Paraná. A destruição florestal causou relevantes distúrbios sobre os recursos hídricos. As precipitações correm rapidamentee carregam do solo importantes nutrientes minerais. Depois de uma elevação inicial do fluxo das nascentes, a baixa contínua do nível do lençol freático leva ao esgotamento do horizonte mais alto da nascemte. Os problemas de abastecimento de água que estão surgindo precisaram ser resolvidos por inúmeras perfurações profundas, como, por exemplo, em Londrina e Maringá. ${ }^{392} \mathrm{O}$ fluxo irregular de água dos rios repentinamente ocasiona enchentes graves.

A destruição da cobertura vegetal originária levou, por meio de intensiva insolação e forte perda de umidade, ao encrostamento superficial do solo através de óxidos de ferro. A destruição das bactérias do solo teve por consequência uma perda significativa de fertilidade do solo.

A permanente erosão do solo fortalece o retrocesso de rentabilidade que ocorre com o esgotamento natural devido ao cultivo permanente sem fertilizantes. ${ }^{393}$ Medições do Instituto Agronômico de Campinas indicam a perda de solo de $750-1875 \mathrm{~m}^{3}$ por alqueire $(=2,42 \mathrm{ha}$ ) e ano (SOUZA, 1965, p. 90 ss.). A forte permeabilidade dos solos arenosos de Caiuá, roubados de sua cobertura vegetal, levou parcialmente a erosões catastróficas. No Norte Novíssimo formaram-se na região em torno de Paranavaí, Nova Esperança, São João do Caiuá, Loanda etc. valas em parte com profundidades de mais de 20 m (MAACK, 1956; KUROWSKI, 1962; KAVALADRIDZE, 1963 e 1966). ${ }^{394}$

No cultivo de café, que se estende, sobretudo, na parte superior dos declives nas encostas, a falta de medidas de proteção do solo e a técnica incorreta de cultivo favoreceram a erosão do solo. A limpeza do terreno ou a aragem entre as fileiras de cafeeiros para o cultivo de culturas intermediárias foram frequentemente realizadas de maneira perpendicular ao declive - assim como a instalação de plantações de café. A falta de sulcos e de terraplanagem para a proteção contra a lavagem do solo tiveram consequências negativas. Apenas recentemente se firmaram o arado de contorno, as drenagens, a instalação de contenções para voçorocas etc. A estrumação, ou seja, a cobertura do solo com material orgânico como proteção contra a erosão, só é feita às vezes no Paraná, apesar da adição ligada a ela de substâncias húmicas, devido à possível disseminação de pragas e por causa da técnica de colheita de derriçagem dos grãos de café sobre o solo.

392 Em Londrina, o fluxo das nascentes diminuiu para um sexto. Cf. sobre isso Maack (1968, p. 241-242) e Idem (1970).

393 Mesmo na 'terra roxa' ocorreram as seguintes perdas de minerais depois de 22 anos de cultivos: 37\% do fósforo, 39\% do molibdênio, $50 \%$ do nitrogênio, $80 \%$ do cálcio, $85 \%$ do magnésio e $93 \%$ do potássio (BARROS, 1956, p. 255 apud Vageler).

394 Em um período de três meses, a erosão levou consigo cerca de 200.000 m³ de areia (MAACK, 1968, p. 244-5). 
Para amplas partes da região arenosa no Noroeste, a única solução econômica para empreendimentos com tamanho pelo menos médio é a transferência para a economia de pecuária. Simultaneamente, as espécies africanas de capim, parcialmente densas e de raízes profundas, oferecem a melhor proteção contra erosão. Na região do arenito Caiuá, a formação de dunas com ventanias de areia e de marcas onduladas levou em alguns casos ao total abandono do cultivo. Essas regiões estão irrevogavelmente perdidas para o uso agrário.

A falta de experiência e a busca especulativa por lucro de proprietários rurais e posseiros e uma reação muito lenta das agências governamentais paranaenses não permitiram, que surgisse até o momento de conclusão desta pesquisa um programa integrado para o combate da erosão. A lei aprovada em 1966 para o impedimento do corte descontrolado e da destruição de florestas chegou com uma década de atraso.

O reflorestamento estabeleceu-se de maneira apenas pontual em áreas pequenas no Norte Novo. Uma vez que os locais mais favoráveis ao reflorestamento são cumeadas, que ao mesmo tempo formam os locais ideais para o cultivo de café, devido ao solo e a particularidades climáticas, não se deve contar com o sucesso do programa governamental nesta região de solos altamente valiosos. A destruição de grandes áreas de floresta dentro de um período de poucas décadas causou rigorosos danos ao ecossistema do Norte do Paraná. O combate às consequências adversas é um problema existencial para o desenvolvimento agrícola futuro.

\section{A AMEAÇA DO CULTIVO DE CAFÉ PELO SURGIMENTO DA HEMILEIA VASTATRIX}

Os problemas da economia cafeeira brasileira - como superprodução com consequente queda de preço, redução de rendimento devido a solos lixiviados pelo cultivo em maior parte desprovido de fertilizantes, erosão do solo e fortes danos causados por geada - foram ampliados em janeiro de 1970 nas principais regiões de cultivo do Paraná e São Paulo pelo surgimento, na Bahia, do fungo da ferrugem do café (Hemileia vastatrix).

A primeira verificação dessa doença fúngica na América do Sul significa uma séria ameaça para o cultivo de café no Brasil, principalmente para as regiões fortemente dependentes do cultivo de café no Norte Novo e partes do Norte Novíssimo do Paraná. As manchas amareladas nas folhas, nas quais se formam esporos de cor alaranjada, surgem a princípio no lado inferior das folhas, onde a infestação da doença se torna visível geralmente em torno do fim da época de chuvas (COOLHAAS; DE FLUITER; KOENIG, 1960, p. 118ss.). As folhas infectadas caem, assim como os galhos fortemente afetados, reduzindo-se assim a produção a um mínimo. Segundo a experiência até o momento, o coffea arabica é especialmente suscetível à Hemileia vastatrix, sobretudo no caso de plantas menos bem tratadas e de menor porte.

O curso da proliferação do fungo da ferrugem do café depois de sua descoberta no Lago Vitória na África Oriental em 1861, passando pelo Ceilão, pelo Sul da Índia em 1869 e Java em 1879, causou pesadas crises econômicas e transformações estruturais da agricultura desses países. No Ceilão, a cafeicultura teve de ser abandonada em favor do cultivo de chá, em Java ocorreu uma transição para a resistente coffea robusta. A produção de café reduziu-se lá, dentro de 30 anos, a 11\% do valor médio anterior à infestação por ferrugem (GERCA, 1970a, p. 6).

Até 1970, a Hemileia vastatrix havia surgido em 33 países produtores de café da África, Ásia e Indonésia; na África ainda no ano de 1952 em Fernando Pó, e em 1966 em Angola. Por outro lado, as Américas Central e do Sul estavam livres do fungo da ferrugem. No caso de um breve caso em Porto Rico, em 1903, o foco da infecção pôde ser destruído.

Em janeiro de 1970, a Hemileia vastatrix foi observada no município de Aurelino Leal no sudeste da Bahia. Após uma confirmação oficial da infestação com base em exames em um instituto especializado em Portugal ${ }^{395}$ foram empreendidas medidas imediatas para a proteção das plantações de café, as quais

395 Desde 1955 existe em Oeiras, Portugal, um ‘Centro de Investigações das Ferrugens do Cafeeiro’. 
previam a erradicação e a destruição dos efetivos de pés de café afetados, bem como a proibição do transporte de café e de sementes de café da região do bloqueio.

Uma pesquisa por amostragem realizada imediatamente nas regiões de cultivo de café dos estados da Bahia, Espírito Santo e Minas Gerais revelou a aparição da Hemileia vastatrix em 107 municípios da Bahia e em 39 municípios de Minas Gerais. ${ }^{396}$ A comprovação do fungo da ferrugem em Caratinga e Simonésia no sul de Minas Gerais alarmou o Instituto Brasileiro do Café, uma vez que essas regiões localizam-se espacialmente isoladas da região originária da proliferação. Ao mesmo tempo, tornou-se evidente a rápida migração da doença das folhas para o sul. No Espírito Santo foram atingidas plantações de café isoladas em 33 municípios, entre eles também no extremo sul do Estado. A proliferação do fungo da ferrugem ocorre por meio da transmissão de esporos no ar com chuva e através das pessoas, em suas roupas, carros, equipamentos etc.

Como principal medida de proteção para os pontos centrais do cultivo de café no sudoeste de Minas, principalmente, porém, em São Paulo e no Paraná, decidiu-se pela instauração de um 'corredor livre de café', estendendo-se por $44^{\circ}$ de longitude ocidental, com uma largura de 35 a $50 \mathrm{~km}$ na região a norte de Belo Horizonte em Minas Gerais em direção ao sul, até o oeste do Rio de Janeiro, estendendo-se por $380 \mathrm{~km} .{ }^{397}$ Nesta faixa de segurança, na qual o cultivo de café possui uma importância muito reduzida, os pés de café disponíveis deveriam ser arrancados para evitar que o fungo da ferrugem continuasse a se proliferar para o oeste e para o sul (DIAS, 1970, p. 39). ${ }^{398}$ Da mesma maneira, pés de café infectados ao longo de estradas de longa distância no sudeste foram arrancados, uma vez que, por conta dos fluxos de trânsito principal em direção ao sul e da migração interna, esporos da Hemileia vastatrix poderiam ser introduzidos nas plantações de São Paulo e do Paraná.

Ao leste do corredor não foram mais realizadas plantações de café subsidiadas, os focos da ferrugem do café deveriam ser totalmente eliminados e a colheita de café dessa região só pôde ser exportada através dos portos regionais. Houve uma uma campanha geral de esclarecimento dos plantadores de café sobre a possibilidade do reconhecimento precoce da infestação da ferrugem, sobre medidas preventivas, como o combate com substâncias protetoras das plantas e um melhor tratamento, principalmente sobre a boa fertilização dos pés de café. Seguiu-se a ela a implementação de um sistema de monitoramento do Instituto Brasileiro do Café.

Além disso, foram realizadas no Instituto Agronômico de Campinas outras tentativas de cultura para obter com a coffea arabica variedades resistentes à ferrugem que já foram cultivadas na Tanzânia, no Quênia e na Etiópia. Pode ser necessária até uma década para que variedades correspondentes sejam testadas e possam ser recomendadas para um cultivo rentável no Brasil. Após uma fase adicional de adiamento, os primeiros resultados se revelam com o alcance da produtividade ideal dos pés de café. Já em abril de 1970, pouco mais de três meses após o descobrimento da Hemileia vastatrix no Brasil, foram disponibilizados 40 milhões de cruzeiros ao IBC para a realização das medidas.

As pesquisas realizadas pelo IBC em maio/junho de 1970 em 2.440 plantações do Norte Velho, Novo e Novíssimo do Paraná com efetivos de pés de café infectados com a ferrugem, revelaram um diagnóstico negativo, assim como em São Paulo e no estado do Rio de Janeiro, embora a última região tenha sido fortemente afetada devido à sua localização. Focos de infecção foram descobertos já em 1970 nos municípios fronteiriços ao corredor. Relatos sobre um surgimento de Hemileia vastatrix no sul de Minas Gerais (DIAS, 1970, p. 36), ${ }^{399}$ imediatamente próximo à fronteira com o estado de São Paulo, o que teria significado uma transposição da faixa de segurança e, portanto uma ameaça direta aos pontos centrais da produção brasileira, a princípio não foram confirmados pelo IBC.

Contudo, em outubro de 1971 o fungo da ferrugem do café, apesar do corredor de bloqueio, após uma proliferação incomumente rápida em direção ao sul, atingiu as regiões de cultivo mais ao sul no Paraná! (WALLER, 1972, p. 403; ROURK, 1972, p. 6). Nesse ínterim tornou-se claro que a ferrugem não pode mais ser eliminada no Brasil. Ao invés disso, deve-se muito mais tentar reorganizar o cultivo de

396 Nas áreas do médio Jequitinhonha, Mucuri, Rio Doce e na Zona da Mata.

397 Revela-se um fator favorável o fato de 58 municípios da região desse corredor possuirem somente cerca de 0,5 milhões de cafeeiros, espalhados em mais de 1.250 empreendimentos.

398 Indica que, até o início de julho de 1970, infelizmente ainda não haviam sido tomadas medidas coordenadas para a implantação desse corredor. De todo modo, já tinha sido preparada uma fórmula de distribuição para as indenizações e concessões de créditos em conjunto com o Banco do Brasil (GERCA, 1970d).

399 Relatório publicado em 04/07/1970: Novo foco de infecção no município de Soledade no sul de Minas, a oeste do corredor! 
café no país e considerar, quando da escolha do local das plantações, outros aspectos ecológicos para a determinação dos espaços naturalmente adequados.

A intensidade da infestação do fungo da ferrugem depende da temperatura, dos volumes de precipitação e distribuição sazonal, incidência de luz e espessura das folhas. Uma vez que a formação dos esporos exige temperaturas médias relativamente elevadas, espera-se estar, no frio inverno do Paraná, a princípio protegido da Hemileia vastatrix. ${ }^{400}$ No entanto, uma vez que as temperaturas mais elevadas coincidem lá com a época de maior precipitação, entre outubro e março, e o Paraná é caracterizado por umidade ao longo do ano todo (Figura 1), o fungo da ferrugem pode se desenvolver bem. Além disso, o sistema brasileiro tradicional de plantação de café (quatro plantas ou mais por buraco) favorece, devido à espessa folhagem dos pés de café que crescem rapidamente sobre os frutíferos solos de terra roxa, a formação de um micro-clima quente e úmido e, com isso, a prosperidade da Hemileia vastatrix. Pés de café situados muito próximos uns aos outros e diversas plantas por buraco revelaram-se desvantajosos - o que no Paraná foi considerado favorável por muito tempo devido às melhores chances de sobrevivência das plantas de café e também da proteção contra a geada e das sombras. Felizmente, o café é plantado no Brasil sem árvores umbrosas, que em geral também favorecem doenças nas plantas.

De acordo com as mais recentes pesquisas do Instituto Agronômico de Campinas, as altitudes abaixo de $700 \mathrm{~m}$ podem ser favoráveis, por motivos de temperatura, à formação de esporos do fungo da ferrugem e inapropriadas, portanto, para o cultivo de café. Em altitudes acima de $900 \mathrm{~m}$ a Hemileia vastatrix não pode mais vingar no Paraná, mas a essas altitudes o risco de geada também aumenta fortemente, de modo que o cultivo de café nesta localização longitudinal no Trópico de Capricórnio atinge seu limite de altitude de 950 a $1.000 \mathrm{~m}$ acima do nível do mar.

Os efeitos da infestação da ferrugem sobre a economia cafeeira brasileira não podem, neste momento de conclusão da pesquisa, ser analisados como um todo. O surgimento da ferrugem significa um perigo sério para as regiões de cultivo intensivo do Paraná, as quais já têm grandes problemas a resolver devido à geada de 1969. Extremamente graves não são apenas as consequências econômicas para o Brasil como um todo, mas também as consequências sociais de uma infestação do fungo da ferrugem em grandes áreas.

No entanto, apesar de todos os aspectos negativos, o IBC vê a possibilidade, com a aplicação dos correspondentes recursos técnicos, sobretudo o emprego de pesticidas, de reduzir o percentual da infestação por ferrugem, de maneira tal que um cultivo rentável de café possa ser mantido (GERCA, 1972, 1970a, 1970b). Considera-se, contudo, que por meio disso seja possível um aumento de 20-30\% dos custos de produção. Os gastos com substâncias para a proteção de plantas por hectare correspondem aproximadamente ao valor de três sacas de $60 \mathrm{~kg}$ de café descascado. Isso significa custos acima de $80 \%$ dos valores médios de rendimento do café por hectare no Brasil (ROURK, 1972, p. 8), o que sugere a concentração do combate químico à Hemileia vastatrix em regiões de rendimento intensivo.

Em regiões em que as condições de temperatura e precipitação favorecem fortemente o desenvolvimento do fungo da ferrugem do café, os pesticidas precisariam ser aplicados com tanta frequência que o cultivo de café se revelaria economicamente inviável.

No Paraná, o desenvolvimento da infestação por fungo da ferrugem levou muitos plantadores que ainda estavam indecisos após a forte geada de 1969, sobretudo na região baixa dos solos arenosos do Norte Novíssimo, ao norte do Rio Ivaí, a uma redução adicional das áreas de cultivo de café, em parte até mesmo a abandonar plantações de café fortemente dependentes de cuidados. A queda de rentabilidade ocorrida nas últimas décadas e os altos investimentos de capital necessários para o combate da Hemileia vastatrix com pesticidas, fertilizantes etc. favoreceram essa tendência de desenvolvimento, especialmente no caso de pequenos empreendimentos.

No Norte Novo, por outro lado, os métodos de cultivo e, sobretudo, o cuidado e o controle das plantações de café foram muito intensificados. Em 1970/1971 as cifras das vendas das empresas de fertilizantes ${ }^{401}$ puderam ser mais do que duplicadas no curso de um ano e continuam a subir, o que não tem como causa última a intenção de cultivar pés de café possivelmente mais fortes que possam resistir melhor ao fungo da ferrugem. A urgente aplicação necessária de pesticidas para o combate à doença nas plantas exige meios financeiros adicionais.

400 Uma temperatura média de pouco mais de $21^{\circ} \mathrm{C}$ parece ser ideal para o desenvolvimento do fungo da ferrugem, com limiares inferior e superior em $15^{\circ} \mathrm{C}$ e $28^{\circ} \mathrm{C}$, respectivamente (informações gentilmente fornecidas pelo IBC, bem como em ROURK, 1972, p. 7).

401 Informações das firmas Ultrafertil (Londrina), Ricasolo (Rolância) e Nortox (Apucarana). 
O impulso que a ameaçadora Hemileia vastatrix causou no Norte Novo do Paraná com a cultura de variedades de 'arábica' resistentes à ferrugem, bem como uma intensificação dos métodos de processamento e plantação no cultivo de café, tem um significado positivo no âmbito da consolidação da economia cafeeira paranaense nos espaços naturais adequados. O destino do cultivo de café paranaense e, com isso, do desenvolvimento do Norte do Paraná depende, contudo, da efetividade das medidas do Instituto do Café para a redução dos danos e perdas nas colheitas causados pela doença do fungo da ferrugem. 